\title{
DE NOVO, O SISTEMA REGISTAL AUSTRÍACO
}

\author{
AGAIN, THE AUSTRIAN REGISTRATION SYSTEM
}

\section{Mónica Jardim}

\begin{abstract}
Professora-doutora em Direito Civil pela Faculdade de Direito da Universidade de Coimbra, onde é regente da segunda turma da disciplina de Direito das Coisas, da disciplina de Direitos Reais II e da disciplina de Direito dos Registos e do Notariado. Presidente do Centro d e Estudos Notariais e Registais. Membro cooptado, por reconhecido mérito científico, do Conselho do Notariado de Portugal. E-mail: mvasjardim@gmail.com
\end{abstract}

Convidada

RESUMO: Através deste estudo pretende-se dar uma perspectiva geral do sistema registral austríaco. Visando tal objetivo, começamos por fazer uma sucinta resenha histórica e breve apresentação da função desempenhada pela publicidade registral, do sistema tabular ou do livro fundiário austríaco, na alteração da situação jurídico-real. De seguida, apresentamos as características do sistema tabular ou do livro fundiário. Posteriormente, analisamos o sistema tabular ou do livro fundiário, nos aspectos que de seguida se enumeram: i) Os livros de registro; ii) Assentos registrais; iii) $\mathrm{O}$ processo de registro; iv). O Recurso do decreto tabular; v). A ação de cancelamento da entabulação/extabulação e a sua anotação; vi). A prescrição extratabular ou contratabular (außerbücherliche Ersitzung). Por fim, examinamos, brevemente, uma figura característica do direito austríaco: a Anmerkung der Rangordnung der beabsichtigten Veräußerung - a anotação da ordem de precedência ou a anotação da ordem de prioridade.

Palavras-chave: O sistema registral austríaco; o sistema de título e modo complexo; Anmerkung der Rangordnung der beabsichtigten Veräußerung/anotação da ordem de precedência ou anotação da ordem de prioridade.

ABSTRACT: This study intends to give a general perspective of the Austrian registry system. In order to achieve this objective, we begin by giving a brief historical review and brief presentation of the role played by the Austrian registry, the tabular system or the land book, in changing the real legal situation. Next, we present the characteristics of the tabular system or the land book. Subsequently, we analyzed the tabular system or the land book, in the aspects that are listed below: i) The register books; ii) Registered seats; iii) The registration process; iv). The Appeal of the tabular decree; v). The action of canceling the entabulation / extabulation and its annotation; vi). The extratabular or contratabular prescription (außerbücherliche Ersitzung). Finally, we briefly examine a characteristic figure of Austrian law: the Anmerkung der Rangordnung der beabsichtigten Veräußerung - the annotation of the order of precedence or the annotation of the order of priority.

Keywords: The Austrian registration system; the title system and complex mode; Anmerkung der Rangordnung der beabsichtigten Veräußerung / annotation of the order of precedence or annotation of the order of priority. 
SUMÁRIO: 1. Sucinta resenha histórica e breve apresentação da função desempenhada pela publicidade registal, do sistema tabular ou do livro fundiário austríaco, na alteração da situação jurídico-real; 2. Características do sistema tabular ou do livro fundiário; 3. Análise do sistema tabular ou do livro fundiário: i) Os livros de registo; ii) Assentos registais; iii) O processo de registo; iv). O Recurso do decreto tabular; v). A acção de cancelamento da entabulação/extabulação e a sua anotação; vi). A prescrição extratabular ou contratabular (außerbücherliche Ersitzung); 4. A Anmerkung der Rangordnung der beabsichtigten Veräußerung austríaca - anotação da ordem de precedência ou anotação da ordem de prioridade.

\section{SUCINTA RESENHA HISTÓRICA E BREVE APRESENTAÇÃO DA FUNÇÃO DESEMPENHADA PELA PUBLICIDADE REGISTAL, DO SISTEMA TABULAR OU DO LIVRO FUNDIÁRIO AUSTRÍACO, NA ALTERAÇÃO DA SITUAÇÃO JURÍDICO- REAL}

O fulcro e o germe do sistema jurídico da transmissão de imóveis na Boémia, que teve decisiva importância na evolução histórica do sistema registal austríaco, foi o instituto do Landtafeln que é qualificado como único no género.

O Landtafeln era público e nele deviam ser inscritos todos os actos jurídicos translativos ou constitutivos de direitos reais que tivessem por objecto bens imóveis. A entabulação no registo, inicialmente, limitava-se a servir de prova do consentimento senhorial - necessário para a validade do acto -, mas, pelo menos, a partir do século $\mathrm{XV}$, passou a ser considerada como elemento imprescindível para a aquisição do direito.

Por força deste instituto foi afirmado o princípio da especialidade - porque, em regra, o registo continha a indicação precisa dos bens e dos negócios relativos a estes - e acabou por ser consagrado o princípio da pública fé (Vertrauenwürdigkeit), uma vez que o funcionário competente (Landtafelbeamte) controlava o título e o direito do disponente (princípio da legalidade).

As Landesordnungen de Fernando II, de 1627 para a Boémia, e de 1628 para a Morávia, consagraram e refinaram os princípios anteriormente adquiridos que passaram a assumir maior importância com a Lei de Fernando II, de 1640.

Em 22 de Abril de 1794, foi promulgada a Lei Hipotecária austríaca que, impondo a eficácia constitutiva da inscrição, introduziu neste território, então pertencente ao Sacro Império Romano-Germânico, o Registo principal (Hauptbuch), tendo em vista agilizar a possibilidade de conhecer o complexo de direitos que onerasse determinado bem imóvel. Com o livro principal foi instaurado o sistema de fólios e rubricas separadas e distintas para cada um dos imóveis, onde passaram a constar os elementos relativos à sua situação jurídica, enquanto os precedentes Registos davam publicidade aos títulos documentais (Instrumenten; Urkundenbücher). Desta forma, por um lado, conseguiu-se, efectivamente, tornar mais célere o conhecimento sobre o complexo de direitos que oneravam determinado imóvel; e, por outro, fortaleceu-se a confiança no Registo, uma vez que o objecto da publicidade deixou de ser o negócio modificativo da situação jurídica do imóvel, passando a ser o resultado do controlo efectuado pelo juiz tabular quanto à ocorrência da modificação jurídico-real.

O Código austríaco de 1811 (Allgemeines Bürgeliches Gesetzbuch für das Kaisertum Osterreichs), ainda vigente, adoptou o sistema do Landtalfen e dos Registos fundiários, sem modificações substanciais, reafirmando, no $\S 431$, a eficácia constitutiva da inscrição (Einverleibung).

O sistema austríaco foi, depois, integrado, através da Lei Geral austríaca de 25-07-1871 e respectivo regulamento de 1872 , por normas relativas à organização e à realização do Registo ${ }^{1}$; lei

\footnotetext{
${ }^{1}$ Data na qual a Áustria já não pertencia à Confederação Germânica. Pois, como se sabe, em 1866 ocorreu a Guerra Austro-Prussiana, na qual a Itália e a Prússia em pouco tempo derrotaram a Áustria e, em consequência, a Confederação Revista de Direito Brasileira | Florianópolis, SC | v. 24 | n. 9 | p.250-273 | Set./Dez. 2019
} 
esta que após várias reformas acabou por dar origem à Grundbuchsgesetz $(G B G)$ de 1955, actualmente em vigor.

Consequentemente, o sistema tabular ou do livro fundiário (Landtalfen) permanece em vigor na Áustria ${ }^{2}$. Assim, neste país, para a aquisição derivada de direitos reais não é suficiente o título ou acordo de vontades entre as partes- ${ }^{3}$. De facto, segundo o $§ 380$ do Código Civil Austríaco não se pode adquirir a propriedade sem título - iusta causa - e legítimo modo de adquirir - modus adquirendi”.

O título, na aquisição derivada, pode ser o contrato, a disposição mortis causa, a decisão judicial ou a disposição legal.

Germânica foi dissolvida. A Prússia formou, então, uma nova confederação sem a Áustria - a Confederação da Alemanha do Norte - tendo a Áustria sido excluída e permanecendo, daí por diante, fora dos assuntos alemães.

${ }^{2}$ Sobre o sistema tabular austríaco vide, entre outros: BÖHM, Sachenrecht, Allgemeiner Teil, Wien, LexisNexis-Verl. ARD Orac, 2003; DEMELIUS, Österreichisches Grundbuchsrecht, Entwicklung und Eigenart, Wien, Manz, 1948; DITTRICH/ANGST/AUER, Das österreichische Grundbuchsrecht, 3. Aufl., Wien, Manz, 1979 e Grundbuchsumstellungsgesetz, Wien, Manz, 1981; DITTRICH/NAGY, Das österreichische Grundbuchsgesetz, Wien, 1962; EHRENZWEIG, System des österreichischen allgemeinen Privatrecht, Das Sachenrecht, 2. Aufl., Wien, Manz, 1957; FRANZ TRIEBEL, Materielles Grundbuchrecht, Tübingen, J. C. B. Mohr, 1938; FEIL, Österreichisches Grundbuchsrecht, ob. cit.; idem, Allgemeines Bürgerliches Gesetzbuch, vol. III, Eisenstadt, Prugg, 1977; FEIL/MARENT/PREISL, Grundbuschsrecht, Wien, Linde, 2005; KLANG, ABGB - Klangs Kommentar, II, Wien, Springer, 1998; KOZIOL/BYDLINSKI/BOLLENBERGER, ABGB - Allgemeines Bürgerliches Gesetzbuch, WienNew York, Springer, 2006; KOZIOL/WELSER, Bürgerliches Recht, II, 13. Aufl., Wien, Manz, 2002; IRO, Bürgerliches Recht IV, Sachenrecht, 2. Aufl., Wien/New-York, Springer, 2002; RUDOLF KAINDL, Project National Report - AUSTRIA, [on-line] consultado em 16 de Outubro de 2006. Disponível: http://www.iue.it/LAW/ResearchTeaching/EuropeanPrivateLaw/Projects/Real\%20Property\%20Law\%20Project/Aus tria.doc; SCHNITZER/FAISTENBERGER/BARTA/CALL, Österreichisches Sachenrecht, Wien, 1998; UNGER, System des österreichischen allgemeinen Privatrechts, Leipzig, Breitkopf und Haertel, 1876; WELSER, in Rummel Kommentar zum ABGB, I, Wien, Manz, 1983; Grundbuchseintragung, [on-line] consultado em 16 de Novembro de 2005. Disponível: http://www.help.gov.at/content.Node/60/Seite.600200.html; The Austrian Land Book (Grundbuch), [on-line] consultado em 16 de Novembro de 2005 em 16 de Novembro de 2005. Disponível: http://www.eurocadastre.org/pdf/auer.pdf; Vários, Online Lehrbuch Zivilrecht, [on-line] consultado em 1 de Novembro de 2007. Disponível: http://www.uibk.ac.at/zivilrecht/buch/autorenliste.html.

${ }^{3}$ No ordenamento jurídico italiano convivem - embora em zonas territorialmente diversas - dois sistemas de publicidade imobiliária: o da transcrição e o do livro fundiário.

O primeiro vigora na generalidade do território italiano, é um sistema de título, segundo o qual os direitos reais se constituem, modificam e extinguem por mero efeito do contrato (cfr. arts. 1376 e 2644 do Código Civil Italiano), e o registo (trascrizione) é apenas condição de oponibilidade dos direitos em face de terceiros - excepção feita à hipótese prevista no $2^{\circ}$ parágrafo do art. 2808 do Código Civil. O segundo nas zonas pertencentes ao império Austro-húngaro antes da I Guerra Mundial.

Ou seja, o sistema do livro fundiário vigora em Itália em toda a Província de Trieste, Gorizia, Trento e Bolzano, em duas comunas do distrito fiscal de Salò, na Província de Brescia, em algumas comunas dos distritos fiscais de Cervignano del Friuli, Palmanosa e Pontebba, na Província de Udine e em duas comunas do distrito fiscal de Asiago, na Província de Vicenza. Nestes territórios, por força do art. 2 do Regio Decreto de 4 de Novembro de 1928 n. 2325 , foi inicialmente mantida em vigor a legislação austríaca, constituída essencialmente pela Lei Geral sobre os Livros Fundiários de 25 de Julho de 1871, n. ${ }^{\circ}$ 95, B.L.I., pela Lei de 25 de Julho de 1871, n. 96, B.L.I. e pela Lei de 6 de Fevereiro de 1869, n. 18, B.L.I.. Posteriormente, o Regio Decreto de 28 de Março de 1929, n. 499, veio regular ex novo a matéria, mas salvaguardou as normas pré-existentes não incompatíveis, sendo, consequentemente, redigido o Nuovo Testo della Legge Generale sui Libri Fondiari.

Por fim, refira-se que o Regio Decreto de 28 de Março de 1929, n. 499 e o Nuovo Testo della Legge Generale sui Libri Fondiari ainda hoje se mantêm em vigor, com as modificações introduzidas pela Lei de 4 de Dezembro de 1956, $\mathrm{n}$. 1376, pela Lei de 29 de Outubro de 1974, n. 594, pela Lei de 8 de Agosto de 1977, n. 574, pelo Dec.-Lei de 31 de Dezembro de 1996, n. 669, pela Lei de 28 de Fevereiro de 1997, n. 30, pelo Decreto legislativo de 19 de Fevereiro de 1998, n. 51 e pela Lei de 24 de Novembro de 2000, n. 340.

Revista de Direito Brasileira | Florianópolis, SC | v. 24 | n. 9 | p.250-273 | Set./Dez. 2019 
O modus adquirendi, para os imóveis, segundo o $§ 431$, do mesmo corpo legal, e o $\S 4$ da $G B G$, é a Einverleibung ou Intabulation, ou seja o registo, que, como se verá, supõe a celebração de um prévio negócio real (Verfügungsgeschäft) ${ }^{4}{ }^{5}$.

\footnotetext{
${ }^{4}$ No que diz respeito à sucessão mortis causa a título de herdeiro, dispõe, ainda, o $§ 797$ do $A B G B$ que ninguém pode adquirir a posse de uma herança com base na sua própria e exclusiva decisão, uma vez que o direito de suceder ao de cuius tem de ser reconhecido judicialmente e é ao tribunal que compete proceder à entrega da herança (Einantwortung). Acresce que, segundo o $\S 819$ do $A B G B$, após o tribunal se pronunciar sobre a aceitação da herança, de reconhecer a qualidade de herdeiro a determinada pessoa e de esta cumprir as obrigações ( $v . g$. obrigações decorrentes de eventuais disposições testamentárias e obrigações fiscais) que sobre si passam a impender, a herança deve-lhe ser entregue e terminar o processo sucessório, mas o herdeiro só virá a adquirir a propriedade dos bens imóveis se der cumprimento ao $§ 436$ do $A B G B$.

Ora, o $\$ 436$ do $A B G B$, ao regular a hipótese em que a transferência da propriedade se funda na Einantwortung, ou seja, na entrega da herança, exige expressamente a Einverleibung ou entabulação, enquanto modus adquirendi para a aquisição derivada das coisas imóveis, de acordo com o prescrito no $§ 431$ do $A B G B$.

No entanto, a verdade é que quer a doutrina quer a jurisprudência austríaca têm negado ao registo, nesta hipótese, carácter constitutivo, tendo reconhecido ao mesmo meros efeitos declarativos, afirmando que o herdeiro adquire a posse e a propriedade com o trânsito em julgado da sentença que decreta a entrega da herança (Einantwortung) e põe termo ao processo sucessório, ou seja, afirmando que na sucessão mortis causa o título é o testamento, a disposição mortis causa ou a disposição legal e que o modus é a Einantwortung. Sobre esta questão vide, por todos: HELMUT BÖHM, Lehre von Titel und Modus, [on-line] consultado em 15 de Novembro de 2006. Disponível: http://zivilrecht2.uibk.ac.at/online_lehre/zivilonline/sachenrecht/titel_modus.html.

Refira-se que esta posição já era defendida por RANDA em 1893, cfr. RANDA, Das Eigenthumsrecht nach österreichischem Recht, Leipzig, 1983, § 17, p. 389-90, apud, GIOVANNI CERVAI, "Libri Fondiari”, loc. cit., p. 904 , nota 4.

${ }^{5}$ Em relação aos territórios da Itália onde vigora o sistema do Livro Tabular, cfr. o art. 2 do Régio Decreto n. 499 de 28 de Março de 1929 , no que diz respeito às aquisições derivadas, voluntárias, inter vivos.

Quanto a todas as outras formas de aquisição (sucessão mortis causa, expropriação, aquisição em venda ocorrida num processo de execução, usucapião, etc.) cumpre referir que em Itália são eficazes independentemente da entabulação, traduzindo-se, portanto, em formas de aquisição extratabular. Porque assim é, o correspondente assento visa, por um lado, "apenas" consolidar a eficácia erga omnes anteriormente adquirida em face de "terceiros" que pudessem vir a beneficiar do princípio da fé pública registal (a inscrição assume, assim, mera eficácia declarativa). E, por outro, legitimar o adquirente do direito real a alienar ou onerar, uma vez que, enquanto a inscrição registal não ocorrer o titular do direito real estará impedido de o fazer de acordo com o princípio da continuidade da inscrição ou do trato sucessivo.
}

Sobre o sistema tabular vigente em Itália vide, entre outros: ARTURO PICCIOTTO, Lineamenti generali del sistema tabulare, principali differenze com il sistema della trascrizione, e procedimento in affari tabulari, [on-line] consultado em 16 de Novembro de 2006. Disponível: http://www.tribunaletrieste.it/documenti/relazioni; BASSI, Cenni storici sull'instituto del libro fondiario, Rivista di Diritto Tabulare, 2, p. 8 e ss.; BRESCH, Le Nuove Leggi sui Libri Fondiari per la Venezia Giulia e Tridentina, Padova, Cedam, 1932; FERRI, Doppia alienazione immobiliare e buona fede nel sistema dei libri fondiari, Rivista Trimestrale di Diritto e Procedura Civile, 1951, p. 1136 e ss.; GABRIELLI/TOMMASEO, Commentario della Legge Tabulare, Milano, Giuffrè, 1999; GASSER, L'Istituto del Libro Tabulare nelle Nuove Province, Trieste, Bibl. giuridica dell'Osservatorio Triestino, 1932; GIANLUCA SICCHIERO, La Trascrizione e l'Intavolazione, Torino, 1993, p. 229 e ss.; idem, La «fede» dal diritto austriaco al sistema del libro fondiario, Contrattto e Impresa, 1994, p. 419 e ss.; GIOVANNI CERVAL, Libri Fondiari, in Novissimo Digesto Italiano, IX, Torino, UTET, 1963, p. 901 e ss.; GIOVANNI GABRIELLI, Libri Fondiari, in Novisimo Digesto Italiano, Apêndice, vol. IV, IMPR-MIG, Torino, UTET, 1983, p. 950 e ss.; LOPEZ MENDEL, Sentido social de las instituciones inmobiliario-registrales de la propiedad en Austria, Revista de Derecho Privado, 1963, p. 226 e ss.; LUIGI MENGONI, L'azione in cancelazione nel sistema dei libri fondiari, Rivista di Diritto Civile, 1972, p. 130 e ss.; idem, L'azione in cancellazione nel sistema dei libri fondiari, Rivista di Diritto Civile, 1972, I, p. 141; idem, Risoluzione per inadempimento e terzi subacquirenti, Rivista del Diritto Commerciale, 1948, p. 300 e ss.; QUARANTOTTO, L'Istituto del Libro Fondiario Ovvero Il Sistema Tabulare di Pubblicità Vigente nelle Nuove Province d'Italia, Trieste, Stab. Tip. Naz., 1963; idem Manuale della Legislazione Tabulare, 3. ed., Trieste, Stab. Tip. Naz., 1962; ROBERTO TRIOLA, Della Tutela dei Diritti - La Trascrizione, ob. cit., p. 299 e ss.; Il Sistema Tabulare $o$ del Libro Fondiario, [on-line] consultado em 16 de Novembro de 2005. Disponível: http://www.regione.taa.it/giunta/librofondiario it/tabulareit.htm.; SERVIZIO DEL LIBRO FONDIARIO, La publicità immobiliare nel sistema del libro fondiario, [on-line] consultado em 16 de Novembro de 2005. Disponível: http://www.regione.fvg.it/istituzionale/uffici/solotesto/libro_cs.htm.; Sistema Catasto - Tabulare, [on-line] $\begin{array}{lllllll}\text { consultado em } & 16 & \text { de } & \text { Novembro } & \text { de } & 2005 . & \text { Disponível: }\end{array}$ Revista de Direito Brasileira | Florianópolis, SC | v. 24 | n. 9 | p.250-273 | Set./Dez. 2019 
Refira-se que também não produz qualquer efeito a modificação ou extinção dos supra referidos direitos sem a relativa inscrição ${ }^{6}$.

No ordenamento jurídico austríaco, a alienação ou oneração e extinção, inter vivos e voluntária, de um direito real sobre um imóvel depende da verificação de três elementos:

a) Um negócio obrigacional válido (venda, permuta, doação, etc.), dito «negócio fundamental» - o título = iusta causa; este produz efeitos meramente obrigacionais, carecendo, em absoluto, de transcendência real ( $§ 1053$ do $A B G B)$.

b) Um distinto negócio de disposição, dito «negócio real» (Verfüngsgeschäft), com o qual as partes, em execução ou cumprimento do negócio obrigacional, acordam sobre a constituição, transferência, modificação ou extinção do direito real em causa; negócio real este cuja validade depende da validade do negócio fundamental ( $\$ 433$ do $A B G B)^{7}$.

c) A entabulação/extabulação no livro fundiário do direito, o que supõe o consentimento do até ali titular registal ${ }^{8}$.

10.

Negócio real e entabulação/extabulação concorrem na formação do modo de aquisição9 -

http://www.agraria.org/estimo\%20economia/catastotabulare.htm.; VOGLI, Tecnologie Informatiche e Regime di Pubblicità dei Beni Immobili, Padova, Cedam, 2002, p. 158.

${ }^{6}$ A inscrição (Einverleibungen) traduz-se no registo incondicionado de um direito (entabulação) ou de um cancelamento (extabulação), que tem por efeito a aquisição, a modificação ou a extinção de direitos tabulares (propriedade, servidão, usufruto, uso, habitação, superfície, hipoteca ...).

${ }^{7}$ É, assim, um negócio real e causal: real, pois a sua única finalidade é a mutação jurídico-real; causal, pois a sua existência, validade e eficácia dependem do negócio obrigacional.

${ }^{8}$ Para que ocorra a entabulação de um direito é necessário que o alienante ou onerante esteja previamente inscrito no Registo e que seja apresentado acto autêntico ou escritura privada que legitime tal inscrição (documento tabular). Por outro lado, o documento tabular deve compreender a cláusula tabular, ou seja, a declaração de consentimento para a inscrição, proferida por quem até ali constou como titular registal; quando tal não ocorra, a declaração pode ser prestada em face do responsável pelo Registo (cfr. § 433 do $A B G B$ ).

Refira-se que, quando o referido consentimento é prestado através de cláusula de entabulação constante do contrato, existe a possibilidade de o alienante ou onerante o revogar enquanto não for emitido o decreto tabular. Tal possibilidade só é afastada quando o adquirente obtém uma prenotação, de acordo com o $§ 35$ da $G B G$ ou solicita a justificação através de uma sentença que supra a falta de consentimento do alienante ou onerante.

${ }^{9}$ Estamos, assim, perante num sistema de título e modo sendo este complexo: uma vez que não se reduz, contra o que poderia pensar-se, à inscrição; envolve, também, o negócio real de execução.

MENGONI, L'azione in cancellazione nel sistema dei libri fondiari, loc. cit., p. 130, nota 1, contesta inclusive a afirmação feita, em geral pelos Autores germânicos, segundo a qual o direito austríaco não exige, para a transferência de direitos reais sobre os bens imóveis, um negócio real (dingliche Einigung) distinto do negócio obrigacional fundamental; contesta ainda a afirmação de que fora de um ordenamento, como o germânico, inspirado no princípio da abstracção das transferências patrimoniais, o requisito da Einigung perde qualquer justificação funcional, uma vez que num ordenamento que consagre o princípio da causalidade a separação do acto de disposição em face do negócio obrigacional deixa de ter relevância, na medida em que a inexistência ou invalidade deste afecta sempre os efeitos translativos daquele.

${ }^{10}$ Diversamente, de acordo com o art. 2 do Regio Decreto de 28 de Março de 1929, n. 499, no sistema do livro fundiário vigente em Itália, o acto de disposição é absorvido pelo negócio obrigacional. De facto, por exemplo, quem vende ou doa um imóvel, sujeito à publicidade do livro fundiário, não se obriga apenas; manifesta, também, a vontade de transferir ou constituir o direito. O negócio é, simultaneamente, obrigacional e dispositivo, não obstante não ser suficiente para produzir o efeito real e ser necessário o registo. Assim, ocorre uma simplificação do processo de transmissão, constituição e modificação dos direitos reais, reduzindo-se os seus elementos a dois, uma vez que o modo não é complexo: o negócio obrigacional (com o qual se perfecciona também o acordo das partes quanto à transferência, constituição ou modificação do direito) - o título; a inscrição do direito no livro fundiário - o modo.

Por outro lado, em Itália, como o acto dispositivo é absorvido pelo negócio obrigacional, não se exige que o proprietário inscrito profira qualquer declaração de consentimento para que possa ocorrer a modificação do estado tabular. De facto, uma vez identificada a vontade de transferir, constituir ou modificar o direito e, assim, de consentir a inscrição a favor do adquirente, com a vontade de vender, de doar, etc. manifestada no negócio fundamental, deixa de fazer sentido subordinar a concessão do decreto tabular ao pressuposto formal de uma declaração escrita de assentimento do actual proprietário. 
Tal não implica, obviamente, que o negócio fundamental ou mero acordo de vontades não produza, por si só, qualquer efeito; ele gera um direito com eficácia obrigacional que pode ser exercido pelo futuro adquirente no confronto do seu devedor, dos sucessores a título universal ou de quem tenha adquirido deste a obrigação correspondente.

Acresce que, embora o negócio fundamental não tenha a virtualidade de alterar a situação jurídico-real, assume a função de iusta causa justificativa da referida alteração ( $\$ 433$ do $A B G B$ e $\S 26$ II da $G B G)$, que só virá a ocorrer com o negócio real de execução e registo no livro fundiário.

O mesmo é dizer que, o sistema austríaco, não obstante ter rejeitado o sistema do título e o princípio da consensualidade, adoptou o princípio da causalidade (nemo plus iuris ad alium transferre potest quam ipse habet), afastando-se, assim, do sistema germânico.

O registo, por seu turno - não obstante ter efeitos constitutivos, pois dele depende a existência do direito, enquanto direito real -, na ausência de um negócio obrigacional e de um negócio real válido e procedente não tem a virtualidade de, por si só, criar o direito ${ }^{11}$.

\section{CARACTERÍSTICAS DO SISTEMA TABULAR OU DO LIVRO FUNDIÁRIO}

Em traços largos, podem apontar-se ao sistema do livro fundiário as seguintes características:

1) O sistema é de fólio real, uma vez que o registo é organizado em torno do imóvel que deve ser individualizado com a máxima exactidão. Tal permite dar a conhecer os direitos que têm por objecto o prédio, mais do que os factos jurídicos que determinam as vicissitudes de tais direitos.

Este sistema constitui um verdadeiro e próprio "estado civil dos bens imóveis" na medida em que dos respectivos registos resultam todas as vicissitudes de circulação de que os mesmos tenham sido objecto - $\S \S 2,3$ e 4 da BGB (princípio da especialidade).

2) $\mathrm{O}$ efeito do registo não é tanto a oponibilidade ou inoponibilidade em relação a terceiros, como o carácter constitutivo que atribui à inscrição, e mais concretamente à entabulação, quando em causa estejam actos tendentes à constituição, transmissão, modificação e extinção de direitos reais em geral sobre bens imóveis - §431 ABGB e $§ 4$ da BGB - (princípio da inscrição).

A inscrição no registo é indispensável para que se opere a constituição, transmissão ou modificação previamente acordada, pois é por ela que se exterioriza erga omnes a mudança jurídica ocorrida, provocando o ingresso de uma nova titularidade no mundo registal.

\footnotetext{
${ }^{11} \mathrm{O}$ processo de registo inicia-se com apresentação do pedido, formulado pelas partes do acto ou por uma autoridade competente (contendo os elementos indicados nos $\$ \S 84$ e 85 da $G B G$ ) ao juiz tabular, acompanhado do título original ou de cópia autêntica $(\$ \S 87$ e 88 da $G B G)$.

O juiz tabular decide mediante decreto, com base no estado tabular existente no momento da apresentação do pedido, e acolhe ou recusa a pretensão, sem que sejam ouvidas as partes ( $\$ 95$ da $G B G$ ) tendo em conta, pelo menos, as condições previstas no $§ 94$ da $G B G$ (inexistência de obstáculos à dita inscrição; inexistência de alguma dúvida justificada sobre a capacidade de disposição; justificação do pedido perante o conteúdo dos documentos juntos; etc.). Com base no decreto que colhe a pretensão procede-se à realização do assento no livro fundiário

Caso o pedido seja no todo ou em parte recusado, o juiz tabular no respectivo decreto (que deve ser anotado de acordo com o $§ 99$ e ss.) deve indicar todos os motivos que obstaram ao acolhimento do pedido (com vista a facilitar um futuro recurso).

O decreto do juiz tabular, de acordo com os $\S \S 118$ e 119 da $G B G$, deve ser notificado, com vista a possibilitar um eventual recurso:

- ao requerente ou àquele a favor de quem se efectua a inscrição, se o pedido não foi apresentado por si ou por seu representante;

- ao titular do direito tabular transferido, modificado ou extinto;

- àquele contra quem se realiza uma anotação;

- no caso de cancelamento total ou parcial de uma inscrição, também a todos a favor de quem tenham sido inscritos, sobre o direito cancelado, ulteriores registos de entabulação ou prenotação;

- no caso de entabulação ou prenotação através das quais sejam transferidos direitos já inscritos a favor de terceiras pessoas, também ao proprietário do imóvel.

A omissão ou a irregularidade da notificação não afecta, todavia, a validade da inscrição tabular (§ 121 da $G B G)$.
}

Revista de Direito Brasileira | Florianópolis, SC | v. 24 | n. 9 | p.250-273 | Set./Dez. 2019 
Por outro lado, a perda da propriedade apenas se produz com o cancelamento do registo (§ 444 in fine).

3) Quando em causa esteja uma aquisição derivada e o título seja um contrato, como já referimos, a inscrição no registo tem por base esse negócio, gerador de obrigações entre as partes (p. ex.: compra e venda), que há-de existir, ser válido e procedente - $\$ 433$ do ABGB e o $§ 26$ II da BGB.

4) O título com base no qual é solicitado o registo está sujeito a um penetrante controlo dos requisitos - não apenas de forma mas, também, em certa medida, de substância - controlo esse que compete aos juízes e não à administração pública - §§ 102 e ss. da GBG (princípio da legalidade).

5) É feita uma aplicação rígida do princípio da continuidade, por força do qual nenhum acto registal é praticado, nem sequer com efeito de prénotação/pré-inscrição, se não existe ${ }^{12}$ ou já não subsiste aquele registo que constitui o seu antecedente lógico $-\S 21$ da GBG (princípio do trato sucessivo).

6) Uma nova inscrição só pode ser efectuada havendo a intervenção do anterior titular inscrito - $\$ 433$ do ABGB (princípio do consentimento).

7) O processo de registo só se desencadeia, em princípio, a pedido de uma das partes ou de uma autoridade competente. A actividade oficiosa não constitui a regra e, por isso, apenas tem lugar quando existe comando legal que a consinta - $\$ 76$ da GBG (princípio da instância).

8) O registo gera a presunção, iuris tantum, da existência, eficácia e da titularidade do direito real; presunção que encontra o seu fundamento no princípio da legalidade, do trato sucessivo e do consentimento, mas que cessa logo que exista declaração judicial de inexistência ou invalidade do título jurídico — Princípio da legitimação ${ }^{13}$.

9) É concedida uma intensa tutela ao terceiro de boa fé que haja adquirido direitos, por negócio jurídico ou não ${ }^{14}$, a título oneroso ou gratuito, de quem, de acordo com o registo, aparece como titular, quer no confronto de quem impugna o título aquisitivo do alienante ( $\$ 63$ da GBG), quer no confronto de titulares de direitos adquiridos à margem do registo, por exemplo, mediante a usucapião, sempre que tais titulares não tenham solicitado, atempadamente, a anotação da acção judicial tendente à apreciação positiva da sua situação jurídica ( $\$ 1500$ da ABGB e $§ 71$ da GBG) - Princípio da fé pública ${ }^{15}$.

Para que a fé pública proteja plenamente o terceiro, .têm de estar verificados dois pressupostos. Um, de carácter objectivo, consiste em que do próprio registo não resulte a sua inexactidão nem conste uma anotação de uma acção de impugnação ou de cancelamento de um assento. Outro, de carácter subjectivo, diz respeito à boa fé do terceiro, que é necessária, pois se carecer dela pode sempre ser prejudicado ${ }^{16}$.

\footnotetext{
${ }^{12} \mathrm{Ou}$ se, pelo menos, não é realizado contemporaneamente aquele registo que constitui o seu antecedente lógico.

${ }^{13}$ Tal presunção, porque iuris tantum, pode ser afastada através de sentença judicial que declare a inexistência do título jurídico ou que o invalide e seja seguida pelo cancelamento da inscrição registal, bem como de uma sentença judicial que julgue procedente uma acção de cancelamento fundada num vício do decreto que haja fundamentado a inscrição (cfr. $\S \S 21,28$ e 61 da $G B G$ ).

${ }^{14}$ Ao contrário do que ocorre no sistema germânico, onde apenas é protegido o terceiro que haja adquirido mediante negócio jurídico.

15 Assim, o sistema tabular, além de desempenhar a função negativa típica dos ordenamentos de cepo latino que consiste na garantia oferecida ao titular registal de que o não registado perante si não existe, desempenha ainda uma função positiva, pois protege aquele que adquiriu de boa fé do titular registal mesmo que o título aquisitivo deste padeça, afinal, de vícios, isto após o decurso do prazo de recurso. E também protege aquele que adquiriu de boa fé do titular registal perante quem adquiriu à margem do registo e não solicitou, atempadamente, a anotação da acção judicial tendente à apreciação positiva da sua situação jurídica.

${ }^{16}$ Quanto a este segundo pressuposto, segundo o $§ 63$ da $G B G$ a tutela da fé pública só deve proteger quem adquire conhecendo apenas a situação revelada pelo livro fundiário, acreditando que esta corresponde à situação real e quando não lhe seja exigível, de acordo com as regras da prudência, que conhecesse a discrepância existente entre a situação registal e extra-registal; a fé pública não deve estender-se a quem inscreveu a sua "aquisição" tendo conhecimento ou Revista de Direito Brasileira | Florianópolis, SC | v. 24 | n. 9 | p.250-273 | Set./Dez. 2019
} 
Por fim, cumpre recordar que, ao contrário do que ocorre no sistema alemão, o terceiro adquirente de boa fé não é protegido imediatamente. Efectivamente, a aquisição ( $a$ non domino) do terceiro só se torna firme depois de prescrita a acção concedida ao verdadeiro proprietário para cancelar a inscrição tabular. Assim, a protecção concedida ao terceiro de boa fé deriva da aquiescência manifestada, pela inércia, do interessado em contestar a inexactidão registal durante o prazo legalmente previsto que, como veremos, depende do facto de o interessado ter ou não sido notificado da entabulação que pretende impugnar.

\section{ANÁLISE DO SISTEMA TABULAR OU DO LIVRO FUNDIÁRIO}

\section{i) Os livros de registo}

É geralmente designado com o nome de livro fundiário ${ }^{17}$ o complexo de registos, actos e documentos, que recolhe e revela, em relação aos imóveis, o estado jurídico dos mesmos, com expressa menção das variações de facto e de direito que vão ocorrendo ao longo dos tempos.

O livro fundiário (Grundbuch) - hoje constante de uma base de dados articulada com o cadastro - subdivide-se nos seguintes livros: o livro principal (Hauptbuch) e o livro de documentos (Urkundenbuch).

desconhecendo culposamente a situação real diversa da tabular. A boa fé exigida é, assim, a boa fé em sentido ético. De má fé está, não só quem conhece a incorrecção do registo, mas também quem, naquelas circunstâncias, teria de presumir a incorrecção.

Não obstante o referido, cabe salientar que o problema da exigência da boa fé - quer em sentido ético quer em sentido psicológico - não se coloca nunca na hipótese de alienação do mesmo imóvel, pelo mesmo dante causa (o titular registal), a mais do que um sujeito. De facto, nesta hipótese o conflito resolve-se a favor daquele que primeiro solicitou a inscrição no livro fundiário, independentemente do seu estado subjectivo (de boa ou má fé), sendo a relevância do elemento psicológico afastada, por um lado, em virtude do silêncio da lei e, por outro, porque é incompatível com o espírito e a estrutura do sistema de inscrição tabular.

Neste sistema, a hipótese de dupla alienação perde relevância, pois o não inscrito não é o inoponível face a terceiros, mas sim o que não existe enquanto direito real. De facto, quando um mesmo imóvel é alienado sucessivamente a duas pessoas, aquele que adquiriu por último, mas registou primeiro, prevalece, não porque tenha adquirido daquele que constava no registo como titular do direito, mas porque não tendo sido perfeccionada a alienação precedente, na realidade, adquiriu de quem continuava efectivamente a ser o proprietário do imóvel. Tratando-se de uma alienação feita por quem tem o poder de dispor do direito, e não de uma alienação de coisa alheia, o estado subjectivo de boa ou má fé do adquirente é irrelevante ( $§ 440$ do Código Civil austríaco e $\S 4$ da GBG). O "segundo" (e verdadeiro) adquirente não invoca, nesta hipótese, que confiou numa situação tabular aparente desconforme com o direito e, portanto, não faz qualquer sentido exigir-lhe boa fé.

A situação tabular ao não publicitar a primeira alienação não publicita uma realidade diversa da juridicamente existente, uma vez que a falta da inscrição impossibilitou a transmissão, consequentemente, mesmo que o "segundo" (e verdadeiro) adquirente no momento em que celebra o negócio fundamental tenha conhecimento do vínculo existente entre o seu dante causa e o terceiro tal não comporta a sua má fé, uma vez que tem apenas conhecimento de um outro vínculo obrigacional, e duas convenções de idêntico conteúdo obrigacional podem coexistir sem estarem viciadas podem é, eventualmente, gerar responsabilidade patrimonial do dante causa comum.

Refira-se, ainda a propósito deste segundo requisito, que, não obstante, por um lado, todos os documentos (que constituem a prova do direito e que sustentam a realização do assento registal) serem arquivados no próprio Registo passando a formar a colecção de documentos (Urkundensammlung) - e, por outro, o $§ 5$ da GBG permitir que no livro principal se realize uma remissão para um aspecto de natureza real contido nos documentos, indicando a cláusula exacta - que, assim, beneficiará da mesma eficácia que teria caso constasse da inscrição registal -, a maioria da actual doutrina e da jurisprudência assinala que a obrigação de consultar os documentos - enquanto pressuposto para beneficiar do funcionamento do princípio da fé pública - é excepcional e encontra-se reduzida a três hipóteses: a) se for realizada a remissão; b) se houver suspeita de que o conteúdo do documento não coincide com o Registo; c) se a consulta for usual.

${ }^{17} \mathrm{Na}$ verdade, na Áustria existem três espécies de livros fundiários: o Grundbuch para os imóveis que não estão fora do comércio jurídico - é a este livro que fazemos referência no texto; o Eisenbahnbuch para as linhas-férreas, aí se inscrevem todos os terrenos pertencentes a uma empresa ferroviária; o Bergbuch para as minas, onde se inscrevem todas as concessões mineiras e os relativos direitos reais.

Revista de Direito Brasileira | Florianópolis, SC | v. 24 | n. 9 | p.250-273 | Set./Dez. 2019 
O livro principal (Hauptbuch) é o livro fundiário propriamente dito, onde devem ser matriculados todos os imóveis segundo a ordem pela qual figuram no cadastro e de acordo com os elementos constantes deste. A cada imóvel, ou conjunto de imóveis que formem uma unidade económica, é destinado um capítulo com um número de ordem. Ou seja, diversamente dos registos imobiliários de base pessoal, o livro fundiário é estruturado sobre uma base real.

A consistência do capítulo tabular só pode ser modificada com a incorporação ou desincorporação de imóveis individuais ou de fracções dos mesmos.

O desaparecimento da base real de um determinado capítulo tabular determina o seu cancelamento; é o que ocorre quando o imóvel tenha deixado de ser objecto da publicidade tabular por efeito, por exemplo, de uma expropriação por utilidade pública.

Cada capítulo tabular é composto por um cabeçalho ou índex e por 3 fólios ou secções, assinalados com a letra $\mathrm{A}, \mathrm{B}, \mathrm{C}^{18}$.

No cabeçalho ou índex consta: o nome e código da área cadastral do imóvel ${ }^{19}$; o número registal do imóvel; a identificação do Tribunal que emitiu o decreto que serviu de base ao registo; a data da apresentação; o número que diz respeito à última alteração registal; etc.

$\mathrm{O}$ fólio A, denominado «fólio de consistência», é repartido na secção A/1 e A/2. Na primeira constam os dados relativos à identificação do imóvel (v.g. número do lote ou parcela; tipo de imóvel; partes componentes; área em $\mathrm{m}^{2}$; endereço; etc.); na segunda constam as alterações do imóvel por efeito de incorporações ou desincorporações, e, caso o imóvel corresponda a um edifício sujeito à propriedade horizontal, a descrição das partes em propriedade exclusiva.

$\mathrm{O}$ fólio $\mathrm{B}$, denominado «fólio da propriedade», contém a entabulação do direito de propriedade individual ou em comunhão, com indicação dos respectivos títulos justificativos, a identificação do titular do direito (nome, data de nascimento, endereço, etc.), bem como as limitações ao livre exercício de tal direito (por exemplo: interdição; inabilitação; falência; etc.). Caso o capítulo tabular compreenda um edifício em condomínio, para este último deve ser utilizado um fólio autónomo.

O fólio $\mathrm{C}$, chamado «fólio dos gravames», deve indicar todos os direitos reais que oneram a propriedade do imóvel (servidão, usufruto, hipoteca, etc.) ou as limitações ao poder de disposição por efeito de penhora de sequestro ou por efeito de cláusulas contratuais (p. ex. pacto de indivisão). Caso o capítulo tabular compreenda um edifício em condomínio, para este último deve ser utilizado um fólio autónomo.

O livro de documentos (Urkundenbuch) é organizado por anos e dele constam as cópias autênticas dos títulos que serviram de fundamento à inscrição no livro fundiário, estando estas inseridas por ordem cronológica, através do número e da data do jornal tabular relativo a cada uma das inscrições.

O livro em apreço é conservado no Tribunal em que foram entregues os documentos.

Ambos os livros, tal como o mapa cadastral (Grundbuchmappe ou Katastralmappe), são públicos, no sentido que qualquer pessoa pode aceder às informações nele contidas, desde que saiba o nome ou número da área cadastral ${ }^{20}$ e o número registal do imóvel em questão.

\section{ii) Assentos registais}

\footnotetext{
18 Sobre este ponto, vide: “The Austrian Land Book (Grundbuch)”, in http://www.eurocadastre.org/pdf/auer.pdf. e "Grundbuchseintragung", in http://www.help.gov.at/content.Node/60/Seite.600200.html.

${ }^{19}$ Existe uma clara conexão entre o livro fundiário e o cadastro devendo estes estar em perfeita concordância, não podendo, por isso, alterar-se a descrição do imóvel constante do registo sem prévia alteração cadastral, nem alterar-se o titular cadastral/titular para efeitos fiscais enquanto não ocorrer uma mutação do titular registal inscrito.

${ }^{20} \mathrm{Na}$ ausência destes dados pode sempre recorrer-se ao mapa cadastral digital para localizar o imóvel e descobrir o número respectivo.
} 
Os assentos no livro fundiário (Grundbuch) distinguem-se, atendendo ao seu conteúdo, segundo o $\S 8$ da GBG, em inscrição, prénotação ou pré-inscrição e anotação.

a) A inscrição (Einverleibungen) traduz-se no registo incondicionado de um direito (entabulação) ou de um cancelamento (extabulação), que tem por efeito a aquisição, a modificação ou a extinção de direitos tabulares (propriedade, servidão, usufruto, uso, habitação, superfície, hipoteca... $)^{21}$.

Para que ocorra a inscrição de um direito é necessário que o alienante ou onerante esteja previamente inscrito no registo e que seja apresentado acto autêntico ou escritura privada que legitime tal inscrição (documento tabular). Por outro lado, o documento tabular deve compreender a cláusula tabular, ou seja, a declaração de consentimento para a inscrição, proferida por quem até ali constou como titular registal; quando tal não ocorra tal declaração pode ser prestada em face do responsável pelo registo.

b) A prénotação ou pré-inscrição (Vormerkungen) é o registo condicionado de um direito ou de um cancelamento, tem por efeito a aquisição a modificação ou a extinção de direitos tabulares sob condição de que venham posteriormente a ser justificados.

Trata-se de um regime aplicável a uma fattispecie civilisticamente já perfeita mas temporariamente desprovida de um qualquer elemento exigido para fins de registo.

Se o acto ou sentença com base na qual se solicita a entabulação não tem todos os requisitos específicos de forma ou de eficácia prescritos para este tipo de registo (por exemplo, a sentença ainda não transitou em julgado ou o negócio consta de documento particular com assinatura não reconhecida, notarial ou judicialmente), mas tem uma causa justa e não padece de vícios visíveis, pode-se proceder à prénotação, a qual, verdadeiramente, é uma entabulação condicionada à superveniência daqueles requisitos de forma ou de eficácia em falta que tornam o título inidóneo à entabulação imediata (§ 35 da GBG e o $\$ 438$ do Código Civil austríaco).

Sendo solicitada a entabulação o juiz pode efectuar oficiosamente a simples prénotação ou pré-inscrição quando constate a falta de requisitos necessários para o registo incondicionado, pois existe a presunção iuris et de iure que a solicitação daquela compreende também a solicitação desta, a menos que o requerente tenha expressamente excluído a prénotação ( $\$ 35$ I e 85 III da GBG).

A prénotação, pela sua natureza, tem eficácia provisória, devendo ser sucessivamente justificada, transformando-se em tal caso em entabulação ou, caso contrário, cancelada.

A justificação é dada: por uma declaração, tendo todos os requisitos para a entabulação, proveniente daquele contra o qual foi registada a prénotação; por sentença transitada em julgado que declare justificada a prénotação; pelo trânsito em julgado da sentença que constituiu o título da pré-notação; pela definitividade do decreto injuntivo.

No momento da justificação a inscrição obtém plena eficácia constitutiva com efeitos ex tunc, ou por outras palavras, transforma-se ex tunc em entabulação com prejuízo para os direitos de terceiros registados após a data da prénotação ${ }^{22}$.

\footnotetext{
${ }^{21}$ Segundo o $§ 12$ da BGB, a entabulação dos direitos, com excepção do direito de propriedade, deve indicar com toda a precisão o conteúdo e a extensão dos mesmos, a fim de assegurar a base real da publicidade imobiliária e com ela a fé sobre os dados revelados pelo livro fundiário.

${ }^{22} \mathrm{O}$ conceito de prénotação ou pré-inscrição do sistema do livro fundiário é muito diverso do direito alemão.

A Vormerkung do direito alemão não é uma inscrição com reserva obtida com base num título translativo, mas sim uma inscrição provisória concedida com base num título atributivo de um direito pessoal (direito de crédito ou potestativo) à transferência de um direito real; inscrição esta que tem por função assegurar o cumprimento da obrigação de transferir assumida pelo devedor.

Sobre a Vormerkung do direito alemão vide, entre outros: WESTERMANN, "Sachenrecht", 5. a ed., Karlsruhe, 1951, $\S 84$, VII, apud, HENRIQUE MESQUITA, "Obrigações reais e ónus reais", Coimbra, Almedina, 1990, nota 217, p. 263; LICHTENBERGER, "Die Vormerkung zur Sicherung Künftiger oder bedingter Ansprüche”, NJW, 1977, p. 755 e ss.; KNÖPFLE, "Die Vormerkung", JuS, 1981, p. 157; BAUER, "Lehrbuch des Sachenrechts", 11. a ed., Munique, 1981, § 20, I, 3; LENT/SCHWAB, "Sachenrecht”, 19. ' ed., C.H. Beck`se Verlagsbuchhandlung, München, 1983, p. 61 e ss.; GURSKY, "§ 883 BGB”, in: AA. VV., Staudinger Kommentar zum BGB, 12. ${ }^{a}$ ed., Berlim, Gruyter, 1987, p.

Revista de Direito Brasileira | Florianópolis, SC | v. 24 | n. 9 | p.250-273 | Set./Dez. 2019
} 
Se a prenotação é cancelada porque o direito pré-anotado é declarado inexistente ou porque a prénotação é declarada injustificada ou porque aquele que a obteve renunciou a ela incondicionalmente, qualquer nova solicitação de nova prenotação deve ser recusada oficiosamente ou com base em simples solicitação da contraparte.

c) A anotação ou menção (Anmerkungen) não diz respeito a direitos reais e pode servir vários objectivos, entre os quais o de dar a conhecer certas condições pessoais (p. ex: a menoridade ou a interdição) ou certos actos ou factos que influenciam o poder de disposição do titular registal (p. ex. o sequestro; a pendência de uma acção judicial tendente ao cancelamento de uma inscrição; a reserva de prioridade para uma futura alienação ou constituição de uma hipoteca - Anmerkung der Rangordnung der beabsichtigten Veräußerung -; etc.).

\section{iii) O procedimento}

O processo de registo inicia-se com apresentação do pedido, formulado pelas partes do acto ou por uma autoridade competente (contendo os elementos indicados nos $\S \S 84$ e 85 da $\mathrm{GBG}^{23}$ ), ao juiz tabular, acompanhado do título original ou de cópia autêntica ( $\$ 87$ e 88 da GBG).

O juiz tabular decide mediante decreto, com base no estado tabular existente no momento da apresentação do pedido e acolhe ou recusa a pretensão, sem que sejam ouvidas as partes ( $\$ 95$ da GBG) tendo em conta, pelo menos, as condições previstas no $\S 94$ da GBG (inexistência de obstáculos à dita inscrição; inexistência de alguma dúvida justificada sobre a capacidade de disposição; justificação do pedido perante o conteúdo dos documentos juntos; etc.).

Não podem ser ordenadas inscrições que não estejam compreendidas no pedido, mesmo que os documentos apresentados justifiquem um pedido mais amplo; igualmente, quando apenas é solicitada uma prenotação, não pode ser ordenada a entabulação, mesmo que esta seja possível ( $\S$ 96 da GBG). Todavia, caso seja solicitada a entabulação, o juiz tabular pode, como referimos, conceder a prenotação, a menos que a mesma tenha sido expressamente excluída pelo requerente (§§ 35 I e 85 III da GBG).

Com base no decreto que colhe a pretensão procede-se à inscrição no livro fundiário segundo uma das modalidades previstas no $\S 8$ da $\mathrm{BGG}^{24,25}$.

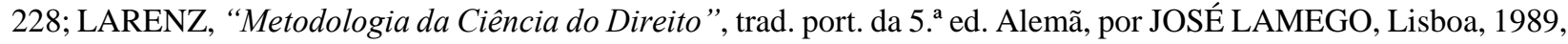
p. 576; EKKEHARD ROSIEN, "Der Schutz des Vormerkungsberechtigten”, Berlim, Carl Heymanns VerlagKG, 1994; MÜLBERT, «Der redliche Vormerkungserwerb», AcP, 1997, p. 335; LUZ MARÍA VELENCOSO, "La protección de los adquirentes de inmubles en el Derecho alemán: Caracteres y efectos de la Vormerkung", in: Revista Critica de Derecho Inmobiliario, n. . 657, Jan. de 2000, p. 669 e ss.; Mónica Jardim, "O Sistema Registal Germânico", Boletim da Faculdade de Direito, vol. LXXVIII, separata, Coimbra, 2002.

${ }^{23}$ Segundo o $§ 84$ o pedido deve conter: a indicação do tribunal competente; os elementos necessários à exacta identificação do requerente (nome, apelido, estado civil e residência); a designação das pessoas que devem ser notificadas e as respectivas residências.

$\mathrm{O} \S 85$, por seu turno, exige que do pedido conste: a exacta indicação do capítulo tabular onde se pretende que ocorra a inscrição e o conteúdo da inscrição pretendida.

${ }^{24}$ Como a inscrição no livro fundiário só pode ocorrer com base no decreto tabular e de acordo com o conteúdo deste, quando, por qualquer causa, a inscrição não possa ser realizada em conformidade com o decreto, o registador tem o dever de solicitar ao juiz a sua rectificação - por exemplo, para tornar o texto do decreto inteligível ou para corrigir eventuais erros materiais que impeçam a inscrição em conformidade com o estado tabular (cfr. § 102 da GBG).

${ }^{25}$ Quando à execução da inscrição vide §§ 102 a 105 da GBG.

O § 104 regula as hipóteses de erro na execução da inscrição, fixando um regime diverso consoante: o erro seja descoberto antes de terminada a execução e, portanto, antes de o público ter acesso a qualquer informação errónea; o erro seja detectado depois de terminada a execução da inscrição no livro fundiário. Na primeira hipótese, o erro pode ser rectificado pelo próprio registador, não exigindo a lei um novo decreto do juiz tabular. Ao invés, na segunda hipótese, é necessário um decreto do juiz tabular para rectificar a inscrição e a referida rectificação não afecta os direitos que terceiros tenham adquirido com base na inscrição errónea.

Revista de Direito Brasileira | Florianópolis, SC | v. 24 | n. 9 | p.250-273 | Set./Dez. 2019 
Caso o pedido seja no todo ou em parte recusado ${ }^{26}$, o juiz tabular no respectivo decreto (que deve ser anotado de acordo com o $§ 99$ e ss.) deve indicar todos os motivos que obstaram ao acolhimento do pedido (com vista a facilitar um futuro recurso).

O decreto do juiz tabular, de acordo com os $\S \S 118$ e 119 da GBG, deve ser notificado, com vista a possibilitar um eventual recurso:

- ao requerente ou àquele a favor de quem se efectua a inscrição, se o pedido não foi apresentado por si ou por seu representante;

- ao titular do direito tabular;

- àquele contra quem se realiza uma anotação;

- no caso de cancelamento total ou parcial de uma inscrição, também a todos a favor de quem tenham sido inscritos, sobre o direito cancelado, ulteriores registos de entabulação ou prénotação;

- no caso de entabulação ou prénotação através das quais sejam transferidos direitos já inscritos a favor de terceiras pessoas, também ao proprietário do imóvel.

A omissão ou a irregularidade da notificação não afecta, todavia, a validade da inscrição tabular (§ 121 da GBG).

\section{iv) $O$ recurso do decreto tabular}

Tem legitimidade para interpor recurso quem tenha visto a sua pretensão desatendida e ainda todos aqueles que resultem directa ou indirectamente prejudicados pelos efeitos do decreto, entre os quais se contam os sujeitos indicados no $\$ 119$ da GBG.

O recurso é apresentado ao juiz tabular ( $\$ 122$ da GBG) para que este possa ordenar a sua anotação no livro fundiário ( $\$ 125$ da GBG de acordo com o $§ 99$ do mesmo diploma), mas é depois apreciado através de decreto pelo tribunal de $1 .^{\mathrm{a}}$ Instância.

Caso o tribunal decida em sentido diverso daquele que foi decidido pelo juiz tabular é admitido recurso para o tribunal hierarquicamente superior, sendo a decisão deste Tribunal insusceptível de recurso ( $\$ 126$ da GBG).

O interessado pode, assim, recorrer do decreto tabular, nos termos dos $\S \S 122$ e ss., sempre que entenda que a decisão do juiz tabular não se harmoniza com o estado dos actos com base nos quais o registo foi requerido - porque, por exemplo, permitiu uma entabulação não conforme com os documentos apresentados. Neste caso o recurso versará sobre o decreto não apreciando a validade ou existência do direito.

Sobre os efeitos decorrentes da procedência do recurso regem os $\S 128$ e 129 da GBG. De acordo com estes artigos, cumpre distinguir consoante em causa esteja um recurso de um decreto que tenha ordenado a inscrição ou um recurso de um decreto que haja recusado a inscrição e tenha, consequentemente, nos termos do $\S 99$ da GBG, conduzido à anotação do pedido objecto de recusa.

Na primeira hipótese - quando em causa esteja um recurso de um decreto que tenha ordenado a inscrição -, sendo julgado procedente o recurso não se procede imediatamente ao cancelamento da inscrição; este só ocorrerá decorrido o prazo previsto na lei para a interposição de um novo recurso ou quando o novo recurso seja julgado improcedente sendo, assim, confirmada a decisão de cancelamento ( $\$ 129$ II da GBG). Quando o novo recurso seja julgado procedente, não confirmando a decisão de cancelamento e dando, assim, razão ao juiz tabular que ordenou a inscrição, deve ser cancelada a anotação do recurso interposto da decisão inicial (§ 129 II da GBG).

$\mathrm{Na}$ segunda hipótese - quando em causa esteja um recurso de um decreto que haja recusado a inscrição -, segundo o $\S 128$, sendo julgado procedente o recurso o juiz tabular deve, oficiosamente, ordenar a inscrição; inscrição esta que será considerada eficaz desde a data em que

${ }^{26}$ É o § 95 II da GBG que reconhece ao juiz a possibilidade de acolher/recusar apenas em parte o pedido. Revista de Direito Brasileira | Florianópolis, SC | v. 24 | n. 9 | p.250-273 | Set./Dez. 2019 
foi efectuado o pedido. Quando, ao invés, o recurso interposto é julgado improcedente o juiz tabular deve cancelar, oficiosamente, a anotação do pedido recusado ( 129 I da GBG).

\section{v) A acção de cancelamento da entabulação/extabulação e a sua anotação}

Segundo o $\S 61$, I da $G B G$, quem for lesado no seu direito por uma entabulação ou extabulação pode impugná-la contenciosamente invocando a sua invalidade com vista a obter o seu cancelamento ${ }^{27}$.

A invalidade do assento registal pode derivar de um vício do decreto que o fundamente ${ }^{28}$ e, nesse caso, a acção de cancelamento concorre com a possibilidade de recurso ( $\$ 122 \mathrm{e} \mathrm{ss.} \mathrm{da}$ $G B G)$, com o qual se impugna o decreto; ou pode derivar de um vício do título com base no qual a entabulação ou extabulação foi concedida e, neste caso, a única solução é a acção de cancelamento $(\S \S 61 \text { e ss. da } G B G)^{29-30}$.

Com a acção de cancelamento (Löschungsklage) apenas se pode pretender impugnar um assento inválido em virtude de um "vício originário" do título com base no qual a entabulação/extabulação foi concedida, uma vez que, no ordenamento jurídico austríaco, a separação entre o negócio obrigacional e o negócio real introduz uma limitação ao princípio da causalidade, na medida em que a dependência causal da alienação ou oneração em face do negócio fundamental é apenas genética, já não funcional. De facto, o direito transfere-se sob a condição de o acto de disposição do titular inscrito e a subsequente inscrição em nome do adquirente se fundarem num negócio obrigacional válido e eficaz, mas aqui termina a relevância do negócio obrigacional fundamental. A transmissão fundada sobre uma «causa válida» torna-se insensível a eventuais vicissitudes resolutivas que posteriormente venham a ocorrer. Se, por exemplo, a venda é resolvida por incumprimento do comprador ou a doação é revogada por ingratidão do donatário, esta vicissitude não incide directamente sobre a alienação e correspondente assento registal que permanece plenamente válido e eficaz ${ }^{31}$. A resolução ou revogação atribuem ao alienante um

\footnotetext{
${ }^{27}$ Refira-se que a acção de cancelamento pode ser proposta quer pelo titular do direito tabular que foi lesado por um assento registal ulterior, quer por aquele que, sendo já titular do direito, ainda não tenha conseguido tornar-se titular registal, precisamente, em virtude do assento impugnável.

${ }^{28}$ A entabulação, por exemplo, foi concedida para um imóvel ou para um direito diverso daquele para o qual foi solicitada.

${ }^{29}$ Quando se pretenda impugnar um decreto que haja rejeitado a entabulação ou a extabulação a única solução é o recurso.

${ }^{30}$ No sistema tabular a invalidade do negócio subjacente propaga-se ao acto de registo: sendo nulo ou sendo anulado o negócio a entabulação é nula por falta de causa.

De facto, de acordo com a teoria da impugnação real (dingliche Anfechtung), a inscrição é inválida quando se baseia num negócio inválido e pode ser impugnada sempre que seja impugnável o negócio que lhe serviu de fundamento (Teoria da autoria de STROHAL, Zur Lehre von Eigentum an Immobilien: Eine Studie aus dem österreichischen Grundbuchsrecht, Graz, 1876, p. 1 e ss. à qual aderiu GIERKE, Der Entwurf des bürgerlichen Gesetzbuchs und das deutsche Recht, Leipzig, Keip, 1898, p. 189, n. 1 e DEMELIUS, Österreichisches Grundbuchsrecht, Entwicklung und Eigenart, ob. cit., p. 62 e ss.. Este último Autor esclarece que esta é a posição da maioria da doutrina, embora geralmente os Autores a expressem de forma implícita).

Fala-se, a propósito, de impugnação real, não no sentido de que a impugnação está relacionada com o direito real, mas para indicar que, em princípio, a sentença é dotada de eficácia real e produz, assim, efeitos para além das partes, nomeadamente, no confronto de sucessores a título particular do titular inscrito - "Der Eintrag aber unterliegt der dinglichen Anfechtung, so gennant, nicht weil sich die Anfechtung aus einem dinglichen Recht ergabe - die Loeschungsklage macht kein dingliches Recht, sondern die Ungültigkeit des Eintrags geltend - sondern weil die Anfechtung dinglich wirksam ist, daher auch gegen die Konkursmasse und gegen die Einzelnachfolger des Eingetragenen durchgreift." (Cfr. DEMELIUS, Österreichisches Grundbuchsrecht, Entwicklung und Eigenart, ob. cit., p. 64).

${ }^{31}$ Ao invés, em Itália, em virtude da identificação do acto de disposição com o negócio obrigacional, a resolução e a revogação eliminam, inter partes, quer os efeitos obrigacionais quer os efeitos reais já anteriormente produzidos, voltando, assim, por força da lei, sem necessidade de retransmissão, o direito real à esfera do alienante. Consequentemente, após a resolução ou revogação, a entabulação do direito em nome do adquirente assume carácter
} Revista de Direito Brasileira | Florianópolis, SC | v. 24 | n. 9 | p.250-273 | Set./Dez. 2019 
simples direito de crédito em face do adquirente, tendo por objecto a retro-transferência do direito. $\mathrm{O}$ alienante não pode, portanto, com base em tais vicissitudes intentar contra o adquirente a acção de cancelamento, a qual pressupõe a invalidade do assento ${ }^{32}$.

Se com a acção de cancelamento (Löschungsklage) se impugna um assento originariamente inválido, cumpre no entanto determinar se a sentença que a julgue procedente afecta ou não os direitos adquiridos por terceiros, uma vez que só assim poderemos apurar em que medida o princípio nemo plus iuris ad alium transferre potest quam ipse habet conhece excepções em virtude da consagração do princípio da fé pública registal.

Contra os "terceiros" cujo direito tenha sido inscrito após a anotação da acção judicial, a sentença que julgue procedente a acção de cancelamento, proposta contra o titular da entabulação impugnada, produz efeitos, uma vez que aqueles não são tutelados pelo princípio da fé pública registal: o referido assento registal provisório de conteúdo negativo, ao advertir os potenciais adquirentes, exclui a boa fé e, consequentemente, o funcionamento do princípio.

De facto, segundo o $\S 61$ I da $G B G$, quem impugna contenciosamente uma entabulação que tenha lesado o seu direito, e solicita a repristinação do estado tabular anterior, pode solicitar ao juiz a anotação da demanda, de modo a afastar o eventual funcionamento do princípio da fé pública registal.

Por efeito da anotação, a posição jurídica dos "terceiros", que adquiriram após a data da anotação da acção, é afectada pela eficácia directa da sentença, não obstante os referidos "terceiros" não terem participado no processo.

Efectivamente, segundo o $§ 61$ II da $G B G$, a sentença que decide a lide será plenamente eficaz no confronto daqueles que tenham obtido direitos tabulares depois da anotação da acção ${ }^{33}$.

lesivo do precedente direito tabular do alienante e verifica-se o pressuposto para que possa ser intentada uma acção de cancelamento (cfr. al. f) do art. 20 da Legge Tabulare). No entanto, a resolução e a revogação não prejudicam direitos adquiridos por terceiros antes da assento de anotação da respectiva acção judicial, e isto quer os terceiros tenham adquirido de boa ou de má fé, conforme prescreve o 3 parágrafo do art. 64-bis, o que é completamente consonante com o facto de o Código Civil italiano não reconhecer à resolução e à revogação eficácia retroactiva em face de terceiros.

${ }^{32}$ Deve, ao invés, solicitar uma nova entabulação a seu favor, com base ou num contrato de retro-transferência do direito - celebrado com o adquirente e que contenha a declaração do consentimento deste último para que seja alterada a realidade tabular - ou numa sentença que substitua o contrato não celebrado voluntariamente

Refira-se, ainda, que o alienante titular da pretensão obrigacional de repristinação do direito à sua titularidade jurídica não tem (ao contrário do que ocorre no ordenamento jurídico germânico: $\S 883 \mathrm{BGB}$ ) a possibilidade de munir tal pretensão de tutela (real) em face de terceiros, mediante um assento registal provisório.

No direito austríaco só é possível assegurar, em face de terceiros, uma pretensão obrigacional que tenha por objecto a modificação de uma situação real através de uma decisão judicial provisória (einstweilige Verfügung), proferida no âmbito de uma acção executiva - e não pelo juiz tabular -, nos termos dos $\S \S 382$ VI e 384 do Regulamento de Execução, com base na qual é inscrita oficiosamente uma limitação do poder de disposição e se dá publicidade ao facto de estar em causa um direito litigioso. Mas esta decisão, para ser proferida, não depende apenas da demonstração do fumus boni iuris (suficiente no direito germânico - § 885 BGB - para obter uma «einstweilige Verfügung» que fundamente uma prenotação nos termos do § 883), mas ainda da demonstração do periculum in mora.

33 Segundo, NEUMANN-LICHTBLAU, Kommentar zur Exekutionsordnung, I, Wien, 1928, sub § 9, p. 77, apud MENGONI, L'azione in cancellazione nel sistema dei libri fondiari, loc. cit., nota 20, o legislador ao estatuir, no § 61 da $G B G$, que a sentença produz plenamente os seus efeitos, contra os "terceiros" que adquiriram após a data da anotação da acção, visou precisar que a referida sentença, além de reconhecer o direito do autor também contra os "terceiros", fornece ao autor vitorioso título executivo para obter do "terceiro" a entrega forçada do imóvel.

Refira-se que o segundo parágrafo do art. 61 do Nuovo Testo della Legge Generale sui Libri Fondiari, vigente em certas regiões de Itália, não impõe a plena eficácia da sentença a "terceiros" que adquiriram após a data da anotação da acção, estatui apenas que "la sentenza che definisce la lite sarà efficace" contra os referidos "terceiros". Acresce que das restantes normas de direito tabular não resulta que a sentença constitua título executivo contra os "terceiros"; de facto, o art. 65 apenas prevê, tal como na Áustria, o cancelamento oficioso de todas as entabulações e prenotações que a partir do direito cancelado tenham ocorrido após a solicitação da anotação da acção. Por isso, MENGONI, últ. loc. cit., considera que a questão de saber se os terceiros também estão sujeitos à eficácia executiva da sentença deve ser resolvida com base no sistema processual italiano. No entanto, o Autor não dá resposta à questão, limitando-se a afirmar que "riceverá soluzione affirmativa o negativa a seconda che nell'uno o nell'altro senso sia resolta l'identica

Revista de Direito Brasileira | Florianópolis, SC | v. 24 | n. 9 | p.250-273 | Set./Dez. 2019 
Acresce que a sentença que julga procedente a demanda, ou seja que declara nula ou ineficaz a entabulação impugnada, ordena o seu cancelamento e envolve, também, o cancelamento oficioso de todas as entabulações e prenotações ${ }^{34}$ que a partir do direito cancelado oficiosamente tenham ocorrido após a solicitação da anotação da acção ( $\$ 65$ da $G B G)$.

Contra o terceiro cujo direito tenha sido inscrito antes da anotação da acção judicial, o autor da acção que pretenda a repristinação do estado tabular, anteriormente existente, tem de promover a impugnação também no seu confronto, uma vez que a entabulação ou prenotação só pode ser cancelada com base em sentença que constitua, também, título de cancelamento da inscrição sucessiva feita a favor de tal terceiro. Mas, a verdade é que tem de distinguir-se consoante o terceiro tenha adquirido de má fé ou, ao invés, de boa fé.

Contra o "terceiro" adquirente de má fé (aquele que conheceu o vício do título do seu dante causa ou o desconheceu culposamente) cujo direito tenha sido inscrito antes da anotação da acção, tal como contra o adquirente imediato, a acção de cancelamento da entabulação pode ser julgada procedente desde que seja intentada por quem veja o seu direito tabular lesado pela entabulação impugnada, enquanto não decorrer o prazo prescricional, previsto na lei civil, próprio da impugnação negocial com a qual é conexa $(\$ 62 \text { da } G B G)^{35}$.

Contra o terceiro de boa fé (que adquiriu confiando na validade da inscrição feita a favor do seu dante causa) e obteve a inscrição do seu direito antes da anotação da acção judicial, a acção de cancelamento está sujeita a um breve termo de decadência, no caso (normal) em que o decreto de concessão da entabulação impugnada tenha sido devidamente notificado ao interessado ( 63 da $G B G$ ); ao invés, quando a notificação não tenha ocorrido validamente, está sujeita a um termo de três anos $(\S 64 \text { da } G B G)^{36}$.

questione proposta dalla norma generale dell'art. 111, ult. Comma, c.p.c.” (A propósito da polémica em torno do art. 111 do Cód.Proc.Civil italiano e da eventual eficácia directa contra "terceiros" das sentenças que julguem procedentes acções sujeitas a registo vide nota 463).

${ }^{34}$ Atentaremos com o pormenor devido ao assento de prenotação, enquanto exemplo típico de reserva de prioridade em sentido impróprio stricto sensu, no final deste trabalho.

${ }^{35}$ Caso exista prazo prescricional, claro está. O que não ocorre, por exemplo, se em causa estiver a nulidade do título ou do decreto tabular).

${ }^{36}$ Refira-se que sobre este ponto o Código Civil austríaco de 1811 não dizia nada em particular. Mas, no $§ 422$, reafirmava, em geral e não de forma circunscrita e limitada, a regra tradicional nemo plus iuris ad alium transferre potest quam ipse habet. Consequentemente, ao ser destruída a aquisição do dante causa, também era a aquisição do "terceiro". O registo não servia para consolidar o seu direito porque não podia legitimar e tornar inatacável um direito real adquirido à margem das imposições legais.

A entabulação, de per se, não constituía prova plena do direito de propriedade, constituía título de posse jurídica (321 e 322 do $A B G B)$ e a posse jurídica ou tabular gerava a presunção legal iuris tantum da titularidade do direito, que, como tal, podia ser destruída mediante prova em contrário.

O limite encontrava-se na usucapião tabular - Tabularersitzung - prevista no Código Civil ( $\$ 1467$ e 1469): quem permanecesse inscrito durante três anos no livro tabular adquiria o direito real ( $\$ 1467 A B G B$ de 1811). Mas, desta forma, o terceiro era protegido porque adquiria a título originário e não a título derivado.

A propósito da Tabularersitzung, cumpre, ainda, referir que se tratava de uma figura muito particular, assimilável, segundo a autorizada doutrina da época, à noção da posse plena e legítima (rechte Gewere); na medida em que, tal como esta, também a hipótese de aquisição do direito entabulado a favor do titular inscrito se baseava, essencialmente, sobre a ideia de aquiescência (Verschweigung), em face de uma situação de facto existente, por parte de quem, sendo interessado, ou tendo legitimidade para se opor, tivesse permanecido inactivo durante um certo lapso de tempo.

Portanto, a referida Tabularersitzung prevista pela $A B G B$ constituía uma aplicação da ideia de Verschweigung; entendida esta última como critério justificativo da aquisição de um direito como consequência da perda ou preclusão do mesmo pelo seu titular, pelo decurso do tempo assinalado ao seu exercício e assumindo, assim, um significado ambivalente, extintivo e aquisitivo.

Um outro aspecto particular desta «usucapião» consistia no facto de ela poder ocorrer independentemente da posse material, bastando-se com a «posse tabular».

Sendo de salientar que o titular inscrito se considerava, para todos os efeitos, possuidor legítimo do imóvel, ou seja titular de posse fundada num justo título e beneficiava da presunção de boa fé constante do $\S 328$ do $A B G B$.

Concretizando: o titular inscrito era havido como possuidor legítimo e desde que não se provasse a sua má fé podia adquirir o direito, mediante a usucapião, decorridos que fossem três anos sobre a data da sua inscrição. A usucapião

Revista de Direito Brasileira | Florianópolis, SC | v. 24 | n. 9 | p.250-273 | Set./Dez. 2019 
Mas, vejamos com mais pormenor.

Na primeira hipótese, o autor que foi notificado validamente da inscrição deve intentar a acção de cancelamento e solicitar a sua anotação no prazo máximo de sessenta dias ( $\$ 123$ da $G B G)$, e, simultaneamente ou antes de decorrido um novo período de sessenta dias, solicitar o cancelamento dos direitos adquiridos por terceiros com base na inscrição impugnada ( $\$ 63$ da $G B G)$.

Desta forma, o cancelamento da inscrição conduzirá à invalidação de todos os direitos adquiridos por "terceiros" de boa fé.

Se, ao invés, o autor notificado não reagir nos termos previstos na lei e dentro dos prazos por ela impostos, não serão prejudicados os direitos adquiridos por terceiros de boa fé antes da anotação da acção $(\S 63, \mathrm{II}, G B G)^{37}$.

$\mathrm{Na}$ segunda hipótese, aquela em que o interessado não foi notificado validamente da entabulação, a sentença que julgue procedente a acção apenas produz efeitos retroactivos em face de "terceiros" de boa fé - que tenham adquirido confiando na validade da inscrição feita a favor do seu dante causa e obtido a inscrição do seu direito antes da anotação da acção judicial - se a acção tiver sido proposta nos três anos posteriores à data da inscrição do direito do próprio terceiro $(\S 64 \text { da } G B G)^{38}$, pois este, decorridos os três anos, passa a beneficiar de uma inscrição inatacável que faz prova plena do direito real $(\S 64 \text { da } G B G)^{39}$.

Em face do exposto, e em resumo, no sistema registal austríaco, o princípio nemo plus iuris ad alium transferre potest quam ipse habet é afastado a favor dos terceiros adquirentes de boa fé, que hajam adquirido antes da anotação da acção. Mas, tal só ocorre depois de decorrido o prazo legalmente previsto para o verdadeiro titular do direito poder reagir, prazo este que pode, verificadas as circunstâncias descritas, ser longo: três anos a partir da data da inscrição do "direito" do "terceiro" de boa fé.

era oponível a quem quer que fosse, podendo o possuidor tabular invocá-la através de uma excepção ou como fundamento para solicitar ao juiz o reconhecimento do seu direito real.

Em face a tais particularidades UNGER afirmou: "nem a posse tabular é verdadeira posse, nem a usucapião tabular é uma usucapião no sentido do direito romano" e, ainda, "tal como se denomina como posse tabular o importante efeito decorrente da inscrição no livro fundiário, também se chama usucapião tabular à aquisição do direito, decorrente da circunstância de contra a inscrição não ter sido deduzida oposição no prazo previsto na lei”. (Tradução nossa).

A $G B G$, de 1871, com o seu $\S 61$ e ss., maxime com o $§ 63$, acabou por excluir a aplicação dos supra referidos artigos do $A B G B$ sempre que em causa estivesse um conflito entre direitos inscritos no livro fundiário. E em 1916, com a reforma do $A B G B$, foram total e definitivamente revogados os $\S \S 1467$ e 1469 do referido corpo legal. (Vide UNGER, System des österreichissen allgemeinen Privatrechts, Leipzig, ob. cit., p. 284. Cfr., ainda, LUIGI MOCCIA, La sicureza degli acquisti immobiliari: figure di «usucapione» e sistemi di publicità immobiliare nella prospectiva del «diritto privato europeu», loc. cit., p. 153).

${ }^{37} \mathrm{O}$ facto de o terceiro de boa fé apenas ser protegido após o prazo previsto na lei para se reclamar do decreto que concedeu a entabulação impugnada justifica-se, na medida em que a entabulação só é assistida de pública fé após o trânsito em julgado do decreto tabular.

No entanto, como é evidente, o terceiro de boa fé, que obtém a seu favor a entabulação após o trânsito em julgado do decreto tabular que permitiu a entabulação a favor do seu dante causa (sessenta dias após a notificação do decreto de entabulação ao interessado - precedente proprietário inscrito), adquire imediatamente o direito ( $a$ non domino).

${ }^{38}$ Em Itália os três anos contam-se a partir da solicitação da entabulação impugnada, ou seja, aquela que foi feita a favor do dante causa do terceiro de boa fé (cfr. art. 64 da Legge Tabulare)

${ }^{39}$ No entanto, cumpre advertir que, como é óbvio, quando, com base na entabulação impugnada, tenham sido obtidas posteriores inscrições tabulares, há que previamente apurar, com base nas regras de direito comum, se a invalidação do negócio que baseou a entabulação impugnada produz ou não efeitos retroactivos. Pois, só quando a retroactividade ocorre é que, após o decurso dos prazos prescritos, entram em jogo os $\S \S 63$ e 64 da $G B G$ que impedem que a acção judicial possa produzir efeitos prejudiciais em relação a terceiros de boa fé.

Assim, por exemplo, se $A$, proprietário tabular de imóvel, o aliena simuladamente a $B$ e este o transfere imediatamente a $C$, que de boa fé celebra o negócio e procede ao registo, $C$, de acordo com o $\$ 916$ II do $A B G B$ nunca verá a sua posição jurídica afectada, uma vez que, segundo este artigo, a simulação é inoponível aos terceiros que, de boa fé, hajam adquirido do simulado adquirente; consequentemente não são aplicáveis as supra referidas normas da $G B G$. (A mesma solução encontra-se consagrada no art. 64-bis da Legge Tabulare).

Revista de Direito Brasileira | Florianópolis, SC | v. 24 | n. 9 | p.250-273 | Set./Dez. 2019 


\section{vi) A prescrição extratabular ou contratabular (außerbücherliche Ersitzung).}

Uma das características mais salientes do sistema jurídico austríaco consiste na previsão, por assim dizer, livre, à maneira dos ordenamentos onde vigora o sistema de protecção mínima, de uma figura da usucapião directamente produtiva de efeitos aquisitivos em consequência da posse (material da coisa ou do exercício de facto do direito) mantida durante um certo lapso de tempo ( $\S 1468,1470,1478,1479$ e 1488 do Código Civil austríaco). Isto a despeito da regra segundo a qual a existência do direito (quer inter partes quer em face de "terceiros") depende da existência da inscrição, no sentido que o direito real surge, transmite-se e extingue-se com a inscrição.

Dada a necessidade da inscrição, o ordenamento austríaco, rigorosamente, devia excluir a possibilidade de as situações de facto contrastantes com a realidade tabular poderem vir a prevalecer sobre esta. Mas, a $A B G B$, em prejuízo do rigor sistemático, optou por dar relevância a certas situações não conformes ao sistema registal, estabelecendo, no $\S 1468$, que: "quando o imóvel não está inscrito em nome daquele que exerce o direito de posse (Besitzrecht), a usucapião só se completa decorridos trinta anos"40.

Não obstante, a verdade é que, segundo o $§ 1500$ do $A B G B$ e o $§ 71$ da GBG, o direito já adquirido mediante a usucapião não pode prejudicar quem sob a fé do livro fundiário tenha adquirido um direito sobre o bem em causa, antes da entabulação do direito usucapido entabulação esta que é lavrada com base na sentença transitada em julgado que reconheça a aquisição originária - ou, na hipótese ser dada publicidade à acção tendente ao reconhecimento do direito adquirido com a usucapião, antes de ter sido lavrada a respectiva anotação.

Portanto, o ordenamento prefere tutelar quem adquire, sob a fé do livro fundiário, do proprietário inscrito em cujo confronto foi amadurecida a usucapião, ao invés de tutelar quem já adquiriu o bem a título originário mas não actuou, atempadamente, por forma a que o Registo passasse a publicitar o seu direito ${ }^{41}$.

Não adquire sob a fé no livro fundiário e, consequentemente, é-lhe oponível a usucapião posteriormente inscrita, quem, no momento da sua aquisição, teve conhecimento ou devia ter tido dos indícios reveladores da posse continuada que deu origem à aquisição originária. Ou seja, não é protegido aquele que afirma ter confiado num "estado tabular", sempre que este seja, manifestamente, negado pela situação material extratabular existente.

Nesta lógica, a falta de um assento registal que publicite, provisória ou definitivamente, a aquisição originária - ou seja, a ausência da anotação da acção tendente ao reconhecimento judicial do direito usucapido ou a ausência da entabulação do próprio direito após o reconhecimento judicial - gera a sua inoponibilidade em face de terceiro que tenha adquirido de boa fé direito com base no livro fundiário, mas não em face de quem sabia que estava a adquirir a non domino ou estava em condições de o saber, através da indagação imposta pela prudência normal, que já havia ocorrido a usucapião. A tutela da fé pública do sistema tabular só deve proteger quem adquire conhecendo apenas a situação revelada pelo livro fundiário, acreditando que esta corresponde à situação real e quando não lhe seja exigível, de acordo com as regras da prudência, que conhecesse a discrepância existente entre a situação registal e extra-registal; a fé pública não deve estender-se

\footnotetext{
40 Tradução nossa.

${ }^{41} \mathrm{Na}$ mesma lógica, o $§ 71$ da $G B G$, regulando o conflito entre assentos registais, tendo um por objecto um direito adquirido derivadamente e outro uma acção judicial de reconhecimento de um direito adquirido por usucapião, estatui que a anotação da acção tendente ao reconhecimento de um direito adquirido com base na usucapião não é eficaz em face de terceiros que sob a fé do livro fundiário hajam obtido anteriormente uma entabulação ou prenotação.

Mas, o direito adquirido através da usucapião, uma vez reconhecido judicialmente, conduz ao cancelamento de todos os direitos incompatíveis registados após a data da anotação da acção judicial.
} 
a quem inscreveu a sua "aquisição" tendo conhecimento ou desconhecendo culposamente a situação real diversa da tabular ${ }^{42}$.

Por último, refira-se que, embora o terceiro adquirente de boa fé prevaleça em face daquele que já usucapiu, está sujeito a perder o direito inscrito em face de quem, à data da sua inscrição, não tenha tempo suficiente de posse que conduza à aquisição originária mas o venha a completar (por exemplo, para apresentar um caso limite, em face de alguém que complete o tempo de posse necessário à usucapião no dia seguinte à da inscrição do direito adquirido derivadamente).

$\mathrm{O}$ acabado de referir, apesar de à primeira vista poder parecer estranho, justifica-se plenamente, quando se tem em consideração que está na disponibilidade do terceiro adquirente, quando o prazo da usucapião ainda não se completou, praticar ou não um acto que interrompa o prazo de posse que pode conduzir à usucapião (mesmo no último dia), e que seria injusto penalizálo pela inércia do predecessor tabular caso a usucapião já tivesse ocorrido ${ }^{43}$ -

42 A exigência da boa fé do terceiro justifica-se, nesta hipótese que se situa ao nível da primeira dimensão da inoponibilidade, desde logo pelo facto de também o possuidor só adquirir originariamente, através da usucapião, se tiver possuído de boa fé.

Em Itália, por força dos parágrafos primeiro e segundo do art. 5 do Régio Decreto de 28 de Março de 1929, n. 499, quem pretender ter adquirido a propriedade ou outro direito real sobre bens imóveis por usucapião ou por outro modo de aquisição originária pode obter a inscrição no livro com base em sentença transitada em julgado que lhe reconheça o direito adquirido ou a extinção do vínculo.

A aquisição de um direito real por usucapião extratabular ("usucapio contra tabulas") opera automaticamente por efeito do decurso do tempo e como a usucapião é regulada pelo Código Civil italiano que é único para toda a Itália, mesmo o possuidor de má fé, ao contrário do que ocorre na Áustria ( $\$ 1477$ do $A G B G)$, pode usucapir. Mas é necessária uma sentença que reconheça a verificação desta facti-species aquisitiva bem como a inscrição do direito originariamente adquirido para que este se torne oponível a terceiros que hajam adquirido por acto inter vivos «sulla fede del libro fondiario». De facto, de acordo com o parágrafo terceiro do art. 5 do Régio Decreto de 28 de Março, n. 499, tal aquisição não prejudica os direitos que terceiros tenham adquirido, por acto inter vivos, «sulla fede del libro fondiario", anteriormente à inscrição ou cancelamento ou a anotação da acção judicial tendente a obter a inscrição ou o cancelamento.

O problema que o referido parágrafo terceiro do art. 5 coloca em Itália é o de se saber qual o significado a atribuir à expressão «sob a fé do livro fundiário». Exigir-se-á ou não a boa fé do terceiro? Sendo esta exigível, a má fé é equiparada à culpa?

Segundo determinada orientação, a boa fé do terceiro é exigível e deve considerar-se de má fé não só quem conhecia mas, também, quem desconheceu culposamente a situação possessória contrária à "realidade" tabular. (Neste sentido, vide GABRIELLI/TOMMASEO, Commentario della Legge Tabulare, ob. cit., p. 30 e ss.).

Numa perspectiva diametralmente oposta há quem afirme que a expressão «sob a fé do livro fundiário» não é equivalente à expressão «aquisição de boa fé» usada em outras disposições legais (nomeadamente no art. 63 e 64 da Legge Tabulare) e que visa sobretudo valorizar ao máximo a eficácia dos Registos públicos no intuito de resolver o conflito entre o direito tabular e extratabular com base no simples critério objectivo do cumprimento do ónus da prioridade do registo, sem atribuir algum relevo ao conhecimento, por parte do terceiro, da efectiva falta de poder de disposição do alienante. (Neste sentido, vide, entre outros: MALTESE, Conflitto, nel codice civile e nella legge tabulare, fra diritto acquistato dal titolare iscritto e diritto usucapito contro il titolare iscritto, Giurisprudenza Italiana, 1973, I, 1, p. 269 e ss.; idem, Usucapione, pubblica fede e buona fede individuale nell'ordinamento tabulare, Giurisprudenza Italiana, 1974, I, 1, p. 121; SICCHIERO, La «fede» dal diritto austriaco al sistema del libro fondiario, loc. cit., 1994, p. 419; idem, Ancora sulla buona fede nel diritto tabulare, loc. cit., p. 515 e ss.).

Numa posição intermédia há quem defenda que a culpa (o poder e dever de conhecer o facto não publicado, com base em indícios extratabulares) não pode ser equiparada à má fé subjectiva (conhecimento em concreto de tal facto), a única que deve relevar, devendo-se, consequentemente afirmar que apenas a prova desta última impede o adquirente do titular inscrito de invocar a tutela contra o adquirente a título originário. (Neste sentido, vide, entre outros: ENRICO ASTUNI, La fede del libro fondiario e l'usucapione, Rivista Giuridica Dell'Edilizia, 2000, Parte I, p. 51 e ss.; GUGLIELMUCCI, Limiti di tutela del titolare di diritti reali inmobiliari non iscritti nel libro fondiario, Giurisprudenza di Merito, 1970, I, p. 252 e ss..).

${ }^{43}$ Neste sentido, vide GABRIELLI/TOMMASEO, Commentario della Legge Tabulare, ob. cit., p. 34. 


\section{A ANMERKUNG DER RANGORDNUNG DER BEABSICHTIGTEN VERÄUßERUNG AUSTRÍACA - ANOTAÇÃO DA ORDEM DE PRECEDÊNCIA OU ANOTAÇÃO DA ORDEM DE PRIORIDADE ${ }^{44}$}

Dependendo a aquisição de direitos reais não apenas de um título válido e procedente mas ainda da celebração do negócio real e da inscrição no livro fundiário, aquele que pretende adquirir o direito não fica seguro pelo simples facto de consultar o livro fundiário antes da formação do título, pois nada lhe garante que não exista um título anterior a favor de um terceiro, ainda não publicado, mas que, entretanto, venha a sê-lo, ou que possa vir a existir um outro título cujo beneficiário consiga publicitar antes do seu.

Para obviar a tal inconveniente os arts. 53 a 58 da GBG austríaco prevê a Anmerkung der Rangordnung ${ }^{45}$.

O titular de um direito real sobre um imóvel, caso pretenda alienar o seu direito ou constituir uma hipoteca pode, antes de realizado o negócio, mediante requerimento donde conste a assinatura reconhecida pelo notário, solicitar a anotação tabular da alienação de tal direito ou da constituição da hipoteca (precisando neste caso o montante máximo da mesma) ${ }^{46}$, sem necessidade de indicar a pessoa do futuro adquirente ou credor ${ }^{47}$, com o intuito de reservar, para a alienação ou hipoteca futura, a prioridade correspondente ao momento da apresentação do requerimento ${ }^{48}$.

${ }^{44}$ Sobre a anotação da ordem de precedência ou anotação da ordem de prioridade vide, entre outros: DEMELIUS, Anmerkung der Rangordnung, Wien, Perles, 1927; FEIL, "Österreichisches Grundbuchsrecht”, Wien/New-York, 1972; LUCIANO SAMPIETRO, "Il ripristino dell'annotazione dell'ordine di grado nel sistema tavolare”, Rivista di Diritto Civile, 1975, 2. " parte, p. 592 e ss.; LUIGI MENGONI, “La pubblicità immobiliare”, JUS, Jan.-Abr., 1986, p. 3 e ss.; LUCIANO SAMPIETRO, Il ripristino dell'annotazione dell'ordine di grado nel sistema tavolare, Rivista di Diritto Civile, 1975, 2. " parte, p. 592 e ss.; GIOVANNI GABRIELLI, "Libri Fondiari”, loc. cit., p. 959 e ss.; HELMUT BÖHM, "Die Rangsicherung im GBG, Weg und BTVG (I) - Ranganmerkung und Vormerkung”, immolex, 1999, in http://ris.aco.net/taweb e "Die Rangsicherung im GBG, Weg und BTVG (II) - Die Anmerkung der Einräumung von Wohnungseigentum ( $\$ 24^{a}$ Abs 2 WEG)”, immolex, 1999, in http://ris.aco.net/taweb.; “Lehre von Titel und Modus”, in http://zivilrecht2.uibk.ac.at/online lehre/zivilonline/sachenrecht/titel_modus.html; QUARANTOTTO, "Per il ripristino dell'annotazione tavolare dell'ordine di rango", Rivista del Notariato, 1967, p. 131 e ss. e "Manuale della legislazione tavolare”, Trieste, 1962, p. 95 e ss.;

${ }^{45}$ Em Itália a figura em apreço já era disciplinada pelos $\$ \S 53-58$ da Lei Geral sobre os Livros Fundiários de 25 de Julho de 1871. Em 1929 foi suprimida do ordenamento jurídico Italiano através do Regio Decreto n. 491 , de 28 de Março - tentando assim evitar a fuga ao fisco -, mas a Lei n. 594, de 29 de Outubro de 1974 reintroduziu-a através do seu art. 40.

A disciplina da figura italiana, assim reintroduzida, é análoga à originariamente prevista pelo ordenamento austríaco, sem, no entanto, ter tido em conta a evolução deste. Nomeadamente o facto de já em 1916 se ter fixado num ano o período de eficácia da anotação em causa para, assim, permitir ao titular do direito uma maior possibilidade de escolha de um idóneo adquirente ou mutuante. E de a GBG de 1955, para limitar o perigo de abuso, oportunamente, ter restringido a 14 dias o período durante o qual o adquirente tem a possibilidade de requerer o cancelamento das inscrições posteriores à anotação.

A Lei Italiana, ao invés, inspirando-se do direito austríaco originário, por um lado, fixou em cinquenta dias o período de eficácia da anotação e, por outro, não colocou qualquer limite temporal à faculdade de requerer o cancelamento de inscrições sucessivas.

46 - A doutrina defende que não deve, através de um argumento de maioria de razão, admitir-se a Anmerkung der Rangordnung nas hipóteses em que o proprietário não pretenda alienar o seu direito, mas apenas onerá-lo com um direito real menor diverso da hipoteca, justificando tal posição no facto de a norma em questão ser excepcional e não poder, por isso, aplicar-se senão às hipóteses nela previstas. (Neste sentido vide, por todos, FEIL, "Österreichisches Grundbuchsrecht”, ob. cit., p. 56).

${ }^{47}$ Segundo HELMUT BÖHM, “Die Rangsicherung im GBG, Weg und BTVG (I) - Ranganmerkung und Vormerkung”, loc. cit. p. 2, através da Anmerkung der Rangordung o proprietário do bem, que limita o seu poder de disposição sobre o bem, pode obrigar-se in certam personam ou em face de pessoa determinada. No mesmo sentido se tem pronunciado parte da jurisprudência austríaca, conforme informa BÖHM, loc. cit., nota 7.

${ }^{48}$ A Anmerkung der Rangordnung consubstancia uma reserva de prioridade em sentido próprio.

Recordamos que a figura da reserva de prioridade registal em sentido próprio, nos ordenamentos jurídicos que a admitem, traduz-se, em traços largos, no seguinte: antes de ser celebrado o negócio jurídico tendente à transmissão ou

Revista de Direito Brasileira | Florianópolis, SC | v. 24 | n. 9 | p.250-273 | Set./Dez. 2019 
O juiz tabular, depois de um controlo meramente formal sobre a legitimidade do requerente emana o decreto de anotação (Rangordnungsbescheid).

$\mathrm{O}$ decreto que ordena a anotação da ordem de precedência ou de prioridade deve indicar a data da apresentação do requerimento e dele apenas pode ser feita uma cópia autêntica, com anotação do pedido, que é entregue ao requerente. Assim, o adquirente que apresente a única cópia existente do decreto pode obter a entabulação ou a prénotação do direito de propriedade ou da hipoteca com a prioridade anotada.

A Anmerkung der Rangordnung mantém a sua eficácia durante um ano ( $§ 55$ da GBG $)^{49}$. Decorrido o referido prazo deve ser cancelada oficiosamente ( $\$ 55$ I da GBG) ${ }^{50}$.

Antes do decurso de tal prazo, o cancelamento da anotação só pode ocorrer mediante a apresentação da cópia autenticada do decreto que a ordenou, na qual deve ser indicado o posterior cancelamento.

Durante o referido prazo deve ser requerida a entabulação ou a prénotação do direito de propriedade com a prioridade da anotação, com base no respectivo título de aquisição acompanhado da cópia autenticada do decreto da Anmerkung der Rangordnung, na qual deve ser feita menção da posterior inscrição ( $\$ 56$ I da GBG).

A pedido daquele que obtém a inscrição do seu direito com a prioridade da Anmerkung der Rangordnung serão canceladas todas as inscrições incompatíveis que, relativamente ao mesmo imóvel, tenham sido feitas após a anotação ( $\$ 57$ da GBG). Desta forma, ocorre uma retroactividade da prioridade da entabulação feita a favor daquele que apresentou a cópia do decreto de anotação; não obstante não se verifica qualquer retroactividade quanto à aquisição do direito, pois este só é efectivamente adquirido no momento da entabulação ${ }^{51}{ }^{52}$.

constituição de um direito real e durante os seus preliminares, dá-se, provisoriamente, publicidade ao direito que dele há-de resultar, criando-se, consequentemente, um obstáculo registal que impede o registo ou que impede o registo definitivo e incondicional de um facto jurídico contraditório com aquele que se encontra em gestação, subtraindo, assim, na prática, o bem imóvel ao tráfico jurídico durante um período determinado.

A figura surge com o objectivo precípuo de eliminar a insegurança, naturalmente existente, de quem, não sendo titular de um direito susceptível de registo, já iniciou o processo de negociações preliminares tendente à aquisição ou oneração de um bem imóvel em concreto ${ }^{48}$.

A reserva de prioridade em sentido próprio visa, portanto, a protecção de um negócio futuro, delimitado ou não. Pretende assegurar o adquirente vindouro perante a inscrição de factos jurídicos que venham a ocorrer entre o momento em que consulta o Registo e o momento em que será celebrado o negócio jurídico produtor de efeitos reais na sua esfera jurídica e o correspondente registo definitivo. Assim sendo, destina-se a garantir a eficácia, em face de "terceiros", de um direito, que ainda não existe na esfera jurídica daquele que passa a beneficiar de protecção registal. ${ }^{49}$ Em Itália a annotazione dell'ordine di grado, como já referimos, apenas mantém a sua eficácia durante cinquenta dias (cfr. art. $55^{\circ}$ da Legge Tavolare).

50 - Não obstante, o proprietário pode posteriormente solicitar de novo uma Anmerkung der Rangordnung.

${ }^{51} \mathrm{Ou}$ seja, a retroactividade da entabulação apenas produz efeitos quanto à prioridade registal, não quanto ao direito de ordem substancial. Assim, por exemplo, o alienante não deve entregar ao adquirente os frutos obtidos no período que medeia a anotação da entabulação. (Neste sentido, vide, por todos: KLANG, ABGB - Klangs Kommentar, II, Wien, 1950, p. 380; LUCIANO SAMPIETRO, Il ripristino dell'annotazione dell'ordine di grado nel sistema tavolare, loc. cit., p. 593, nota, 3).

${ }^{52}$ Reconhecendo-se ao adquirente beneficiado com a anotação da ordem de precedência a possibilidade de requerer o cancelamento das inscrições subsequentes incompatíveis com o seu direito, nos termos anteriormente expostos, há que afirmar que este instituto afecta a disciplina, prevista no $\S 440$ do $A B G B$, bem como no $\S 4$ da $G B G$, de um eventual conflito entre dois adquirentes do mesmo autor. Na verdade, segundo estes artigos, prevalece o adquirente que primeiro solicita a inscrição do seu direito, independentemente de estar de boa ou má fé, e isto mesmo que tenha celebrado o negócio aquisitivo por último, uma vez que adquire a domino por não ter sido perfeccionada a alienação ou oneração precedente. Ora, por força da anotação da ordem de precedência o adquirente que prontamente obtenha a inscrição do seu direito deve sucumbir no confronto do segundo que, por força do decreto de anotação, obtém prioridade através da segunda inscrição, e isto quer este esteja de boa ou de má fé.

Do acabado de referir, já resulta evidente o risco de utilização do instituto com objectivos fraudulentos.

Assim, por exemplo, pode acontecer que o alienante do direito de propriedade, imediatamente após a celebração do negócio jurídico, antecipando-se ao adquirente, solicite ao juiz tabular o decreto de anotação, que lhe será concedido

Revista de Direito Brasileira | Florianópolis, SC | v. 24 | n. 9 | p.250-273 | Set./Dez. 2019 
A Anmerkung der Rangordnung como que cristaliza, desta forma, o estado tabular existente no momento da sua inscrição ${ }^{53}$.

Quanto à hipótese de falência a GBG austríaca, no § 56 III, disciplina de forma expressa o conflito entre a anotação da sentença declarativa de falência e a entabulação baseada em prévia Anmerkung der Rangordnung, dispondo que, em caso de falência anterior à entabulação, esta é admitida quando dos documentos resultar que o contrato já estava exarado antes do dia da declaração de falência. O legislador austríaco acolheu, assim, a possibilidade de ser efectuada a inscrição no Rangordnung anotado, não obstante já ter sido declarada a falência, sempre que o título, com base no qual a inscrição é requerida, tenha data anterior à da dita declaração ${ }^{54}{ }_{-}^{55}$.

uma vez que continua a ser o proprietário do imóvel. Obtido o decreto, o alienante pode vender o imóvel uma segunda vez, entregando ao novo adquirente o decreto, por força do qual este virá a prevalecer no confronto com o primeiro adquirente.

Desta forma, a figura em apreço introduz no sistema tabular a possibilidade de um efectivo conflito entre adquirentes de direitos incompatíveis do mesmo autor ou causante.

Desta forma, a figura em apreço introduz no sistema tabular a possibilidade de um efectivo conflito entre adquirentes de direitos incompatíveis do mesmo autor ou causante.

Nestes termos, um adquirente, para estar certo da sua aquisição, deve exigir do alienante a execução da anotação da ordem de precedência e a entrega do correspondente decreto.

${ }^{53}$ Não obstante, em Itália, a maioria da doutrina - tendo em conta a ratio da annotazione dell'ordine di grado (garantir o potencial adquirente contra eventuais iniciativas incompatíveis por parte do titular inscrito, mas não contra eventuais iniciativas de terceiros dirigidas contra aquele) - afirma que o cancelamento de inscrições posteriores à annotazione dell'ordine di grado apenas pode ocorrer quanto às inscrições que assentem em título dispositivo proveniente do titular inscrito que requereu e obteve a anotação. Consequentemente, defende que não se deve ordenar o cancelamento de uma anotação de acção judicial que, entretanto, tenha sido proposta contra o titular inscrito. Seria paradoxal, afirmase, que uma simples declaração unilateral do proprietário/devedor pudesse subtrair o bem à satisfação dos credores.

Neste sentido, por todos, vide: GABRIELLI/TOMMASEO, ob. cit., p. 530; GABRIELLLI, "La publicità inmobiliare del contratto preliminare", in Rivista di Diritto Civile, Jul.-Ag., 1997, p. 535. e "Libri Fondiari", loc. cit., p. 959 e 960. Esta posição é contestada por alguns autores italianos que entendem que a mesma envolve para o credor que intenta a acção executiva e obtém a penhora uma maior tutela do que aquela que é oferecida ao terceiro adquirente do imóvel, que, como se viu sucumbe em face de quem, embora inscrevendo o seu direito posteriormente, reserva para a sua inscrição prioridade através do decreto de anotação. E tal consequência parece em contraste com o princípio, consagrado no último parágrafo do art. 2915 do Código Civil italiano, nos termos do qual apenas são ineficazes no confronto do credor os actos e acções, que estando sujeitos a registo, o tenham sido posteriormente ao acto da penhora. Da análise conjugada deste artigo com o art. 2913 do mesmo corpo legal - nos termos do qual não produzem efeito no confronto do exequente, e dos demais credores que intervenham na execução, os actos de alienação de bens penhorados - estes autores retiram a conclusão de que ao credor é oferecida, em geral, uma tutela idêntica à de um terceiro adquirente. E, com base nesta argumentação, consideram ilógico atribuir ao credor, nesta hipótese, uma maior tutela do que aquela que é oferecida ao terceiro adquirente. Se o art. 2915 do Código Civil constitui o «limite extremo da tutela concedia ao credor penhorante", dizem, não se pode deixar de concluir, como para o terceiro adquirente, pela aplicabilidade do art. 57 da Legge Tavolar ao registo da penhora. (Neste sentido, vide: LUCIANO SAMPIETRO, "Il ripristino dell'annotazione dell'ordine di grado nel sistema tavolare", loc. cit., p. 598).

Mas, a supra referida argumentação não é acolhida junto da doutrina maioritária, pois esta considera que, assim, se desvirtuaria o objectivo para o qual foi criada a figura e lembra que podendo o proprietário devedor manter continuamente anotada uma reserva de prioridade, na prática, equiparar os que actuam contra ele àqueles que dele adquirem voluntariamente, é admitir que o proprietário do bem retire da garantia patrimonial dos seus credores aquele específico bem

${ }^{54}$ Em Itália, ao invés, a lei não prescreve a solução de tal conflito, e isto não obstante o legislador italiano, aquando da reintrodução do instituto dell 'annotazione dell'ordine di grado ter reproduzido fielmente o modelo austríaco. Portanto, a não reprodução da solução austríaca não deve ter sido casual; terá ficado a dever-se ao facto de não ser conforme aos princípios e normas que regulam o processo de falência em Itália. Consequentemente, após a anotação da sentença declarativa de falência, não é admitida a entabulação baseada em prévia annotazione dell'ordine di grado quer o contrato de alienação ou oneração tenha sido celebrado antes quer depois da data da anotação da sentença.

${ }^{55}$ Como resulta do exposto, estamos perante uma reserva de prioridade em sentido próprio bem distinta das hipóteses de reserva imprópria como o é a Vormerkung do direito alemão.

De facto, embora na prática a Vormerkung do direito alemão desempenhe uma função próxima à da Anmerkung der Rangordung do direito austríaco, ou seja, a função de garantir o futuro adquirente ou o futuro credor hipotecário em

Revista de Direito Brasileira | Florianópolis, SC | v. 24 | n. 9 | p.250-273 | Set./Dez. 2019 


\section{REFERÊNCIAS}

ARTURO PICCIOTTO, Lineamenti generali del sistema tabulare, principali differenze com il sistema della trascrizione, e procedimento in affari tabulari, [on-line] consultado em 16 de Novembro de 2006. Disponível: http://www.tribunaletrieste.it/documenti/relazioni.

BASSI, Cenni storici sull'instituto del libro fondiario, Rivista di Diritto Tabulare, 2. BAUER, “Lehrbuch des Sachenrechts”, 11. 'ed., Munique, 1981, § 20, I, 3.

BÖHM, Sachenrecht, Allgemeiner Teil, Wien, LexisNexis-Verl. ARD Orac, 2003.

BRESCH, Le Nuove Leggi sui Libri Fondiari per la Venezia Giulia e Tridentina, Padova, Cedam, 1932.

DEMELIUS, Österreichisches Grundbuchsrecht, Entwicklung und Eigenart, Wien, Manz, 1948.

DITTRICH/ANGST/AUER, Das österreichische Grundbuchsrecht, 3. Aufl., Wien, Manz, 1979 e Grundbuchsumstellungsgesetz, Wien, Manz, 1981.

DITTRICH/NAGY, Das österreichische Grundbuchsgesetz, Wien, 1962.

EHRENZWEIG, System des österreichischen allgemeinen Privatrecht, Das Sachenrecht, 2. Aufl., Wien, Manz, 1957. EKKEHARD ROSIEN, “Der Schutz des Vormerkungsberechtigten”, Berlim, Carl Heymanns VerlagKG, 1994.

FEIL, Allgemeines Bürgerliches Gesetzbuch, vol. III, Eisenstadt, Prugg, 1977.

face de eventuais actos de disposição do direito adquirido medio tempore por um terceiro, do ponto de vista da técnica registal, e dos respectivos efeitos, os dois institutos são profundamente diversos.

O registo da Vormerkung é solicitado por aquele que tem direito à transferência do direito real ou à constituição de um direito real menor contra o titular registal inscrito, e tem por efeito tornar os actos de disposição posteriores a favor de terceiros relativamente ineficazes na medida em que prejudiquem a pretensão do titular. O registo da Vormerkung tal como, entre nós, o registo do contrato promessa dotado de eficácia real -, é feito a favor e no interesse daquele que pretende adquirir; com o registo não é o obrigado à alienação ou oneração que se autolimita, é aquele que pretende adquirir, e já é titular de um direito de crédito, que se protege assegurando a esse direito eficácia típica dos direitos reais, para que ele venha a prevalecer em face dos actos dispositivos conflituantes. Actos estes que são ineficazes quer assentem quer não num acto de vontade do titular registal.

Ao invés, a Anmerkung der Rangordung do direito austríaco é solicitada, mediante requerimento donde conste a assinatura autenticada pelo notário, pelo proprietário inscrito que pretende alienar o seu direito ou constituir uma hipoteca, e isto antes de realizado o negócio e mesmo sem indicação da pessoa do futuro adquirente ou do futuro credor garantido. E o seu efeito consiste em «reservar para a alienação ou oneração futura a prioridade correspondente ao momento da apresentação do requerimento de reserva». Mas tal reserva só é eficaz em face de inscrições sucessivas de direitos incompatíveis que assentem em título dispositivo proveniente do titular inscrito, que podem, por isso, ser canceladas a pedido de quem venha a obter a inscrição da propriedade ou a hipoteca no grau de prioridade reservado. A dita reserva já não assegura o futuro adquirente em face de inscrições que assentem em actos praticados por terceiros contra o titular registal ( $v . g$., acção executiva entretanto proposta contra o titular inscrito). Assim, consente-se ao proprietário do bem que limite o seu poder de disposição sobre o bem, obrigando-se, in certam personam ou em face de pessoa determinada, a não praticar actos incompatíveis com aquele garantido pelo decreto de anotação, mas não se lhe consente a utilização da anotação como forma de obter protecção em face de uma eventual actuação legítima de um terceiro. (Sobre a distinção entre uma reserva em sentido próprio e uma reserva em sentido impróprio vide Mónica Jardim, Efeitos Substantivos do Registo Predial - Terceiros para Efeitos do Registo, Colecção Teses, Coimbra, Almedina, 2013, p. 109 e ss.)

Revista de Direito Brasileira | Florianópolis, SC | v. 24 | n. 9 | p.250-273 | Set./Dez. 2019 
FEIL/MARENT/PREISL, Grundbuschsrecht, Wien, Linde, 2005.

FERRI, Doppia alienazione immobiliare e buona fede nel sistema dei libri fondiari, Rivista Trimestrale di Diritto e Procedura Civile, 1951.

FRANZ TRIEBEL, Materielles Grundbuchrecht, Tübingen, J. C. B. Mohr, 1938.

GABRIELLI/TOMMASEO, Commentario della Legge Tabulare, Milano, Giuffrè, 1999.

GASSER, L'Istituto del Libro Tabulare nelle Nuove Province, Trieste, Bibl. giuridica dell'Osservatorio Triestino, 1932.

GIANLUCA SICCHIERO, La Trascrizione e l'Intavolazione, Torino, 1993.

GIANLUCA SICCHIERO, La «fede» dal diritto austriaco al sistema del libro fondiario, Contratto e Impresa, 1994.

GIERKE, Der Entwurf des bürgerlichen Gesetzbuchs und das deutsche Recht, Leipzig, Keip, 1898

GIOVANNI CERVAL, Libri Fondiari, in Novissimo Digesto Italiano, IX, Torino, UTET, 1963.

GIOVANNI GABRIELLI, Libri Fondiari, in Novisimo Digesto Italiano, Apêndice, vol. IV, IMPR-MIG, Torino, UTET, 1983.

GURSKY, “§ 883 BGB”, in: AA. VV., Staudinger Kommentar zum BGB, 12. ed., Berlim, Gruyter, 1987.

HELMUT BÖHM, Lehre von Titel und Modus, [on-line] consultado em 15 de Novembro de 2006. Disponível:

http://zivilrecht2.uibk.ac.at/online_lehre/zivilonline/sachenrecht/titel_modus.html.

HENRIQUE MESQUITA, “Obrigações reais e ónus reais”, Coimbra, Almedina, 1990, nota 217.

IRO, Bürgerliches Recht IV, Sachenrecht, 2. Aufl., Wien/New-York, Springer, 2002.

KLANG, ABGB - Klangs Kommentar, II, Wien, Springer, 1998.

KNÖPFLE, “Die Vormerkung”, JuS, 1981.

KOZIOL/BYDLINSKI/BOLLENBERGER, ABGB - Allgemeines Bürgerliches Gesetzbuch, Wien-New York, Springer, 2006.

KOZIOL/WELSER, Bürgerliches Recht, II, 13. Aufl., Wien, Manz, 2002.

LARENZ, "Metodologia da Ciência do Direito”, trad. port. da 5. ed. Alemã, por JOSÉ LAMEGO, Lisboa, 1989.

LENT/SCHWAB, “Sachenrecht”, 19. ' ed., C.H. Beck`se Verlagsbuchhandlung, München, 1983.

LICHTENBERGER, "Die Vormerkung zur Sicherung Künftiger oder bedingter Ansprüche”, NJW, 1977. 
LOPEZ MENDEL, Sentido social de las instituciones inmobiliario-registrales de la propiedad en Austria, Revista de Derecho Privado, 1963.

LUCIANO SAMPIETRO, Il ripristino dell'annotazione dell'ordine di grado nel sistema tavolare, Rivista di Diritto Civile, 1975, 2. ${ }^{a}$ parte.

LUIGI MENGONI, L'azione in cancelazione nel sistema dei libri fondiari, Rivista di Diritto Civile, 1972.

LUIGI MENGONI, L'azione in cancellazione nel sistema dei libri fondiari, Rivista di Diritto Civile, 1972, I.

LUIGI MENGONI, Risoluzione per inadempimento e terzi subacquirenti, Rivista del Diritto Commerciale, 1948.

LUZ MARÍA VELENCOSO, "La protección de los adquirentes de inmubles en el Derecho alemán: Caracteres y efectos de la Vormerkung”, in: Revista Critica de Derecho Inmobiliario, n. ${ }^{\circ}$ 657, Jan. de 2000.

MÓNICA JARDIM, Efeitos Substantivos do Registo Predial - Terceiros para Efeitos do Registo, Colecção Teses, Coimbra, Almedina, 2013.

MÓNICA JARDIM, “O Sistema Registal Germânico”, Boletim da Faculdade de Direito, vol. LXXVIII, separata, Coimbra, 2002.

MÜLBERT, «Der redliche Vormerkungserwerb», AcP, 1997.

QUARANTOTTO, L'Istituto del Libro Fondiario Ovvero Il Sistema Tabulare di Pubblicità Vigente nelle Nuove Province d'Italia, Trieste, Stab. Tip. Naz., 1963.

QUARANTOTTO, Manuale della Legislazione Tabulare, 3. ed., Trieste, Stab. Tip. Naz., 1962.

RUDOLF KAINDL, Project - National Report - AUSTRIA, [on-line] consultado em 16 de Outubro de 2006. Disponível:

http://www.iue.it/LAW/ResearchTeaching/EuropeanPrivateLaw/Projects/Real\%20Property\%20L aw\%20Project/Austria.doc.

SCHNITZER/FAISTENBERGER/BARTA/CALL, Österreichisches Sachenrecht, Wien, 1998.

UNGER, System des österreichischen allgemeinen Privatrechts, Leipzig, Breitkopf und Haertel, 1876.

VOGLI, Tecnologie Informatiche e Regime di Pubblicità dei Beni Immobili, Padova, Cedam, 2002.

WELSER, in Rummel Kommentar zum ABGB, I, Wien, Manz, 1983.

WELSER, Grundbuchseintragung, [on-line] consultado em 16 de Novembro de 2005. Disponível: http://www.help.gov.at/content.Node/60/Seite.600200.html. 